\title{
Seljuks Inherit to Anatolia; Caravanserais
}

\author{
By Tuğçe Darendeli ${ }^{*} \&$ Can Şakir Binan ${ }^{ \pm}$
}

\begin{abstract}
The history of Anatolia intertwined and layered manner is composed of many historical mosaic of culture. In this chronology, we see the Anatolian Seljuk State in the administration of the era when Turkish identity was set up in Asia Minor. This state has become an important force especially in the $11^{\text {th }}$ and $13^{\text {th }}$ centuries, even if it is not absolute in commercial, military and economic. At that time, the continuity of the state union was due to the intense trade and lack of scarcity in the country. The Seljuks were aware of this. With the expansion of Anatolian Seljuk State borders, which gives importance to the trade, new road networks have been formed and the existing ones have been strengthened. Old Anatolian cities such as Konya, Kayseri, Sivas and Erzurum have become important trade centers. It is necessary to ensure the safety of the roads and caravans in all of this commercial activity in the country. Caravanserais and khans were constructed on the roads to meet the needs of the caravans in order to stay and to continue their way. These buildings, which have an enclosed architecture with thick masonry walls, look like a castle and have become a power show. Anatolian Selcuklu period caravanserais show different features than the previous accommodation structures. In this study, the change of the commercial activities and accommodation during the history and the spatial organization, plan typologies and functions of the Anatolian Seljuk Caravanserai constructions are discussed.
\end{abstract}

\section{Development of Historical Roads and Trade Concept}

Since the beginning of history roads of economic, social and military terms it has had a great importance all the time. Transportation of commodities, military movements and communication between societies have always been achieved through means. Therefore, all civilizations throughout history have made great efforts to maintain their power. The roads have continued to exist in every period of mankind. With the development of mankind and civilizations, paths have also developed.

People used the natural ways of shaping animals in the early times. These roads, also known as 'goat roads' formed by animal tracks, have been transformed into patrols and pedestrian paths with increasing use over time. Some of these roads are also the basis of today's roads. ${ }^{1}$

Bridges, caravanserais and other accommodation structures, towers, landmarks, postal organizations and similar structures have been the most important elements in understanding the ways the caravans have passed. The shortest, most reliable and unstable routes between the two points were determined

\footnotetext{
*Research Assistant, Yildiz Technical University, Turkey.

${ }^{ \pm}$Professor, Yildiz Technical University, Turkey.

1. E. Çetin, "Franz Taeschner'in Muhtelif Devirlerde Anadolu'nun Yolları Ve Cihan Münakalatına Nazaran Vaziyeti İSsimli Eseri ÜzeriNe Notlar,” Tarih Okulu Dergisi 17 (2014): 324.
} 
when the routes were formed. Being close to water resources is important in terms of the location of the roads and settlements, such as land ruggedness, desert, climate. ${ }^{2}$ These roads have taken many years to form.

Some roads have gained importance in some periods of history. The routes used have changed for various reasons and have been characterized by various names in the period. Some of these routes, named according to the commercial goods they carry and their functions. Examples of these routes are the Hittites, the roads of the Assyrian trade columns, the Persian King Road, the Roman Road and the Byzantine road network, and the Silk Road (see Figure 1). ${ }^{3}$

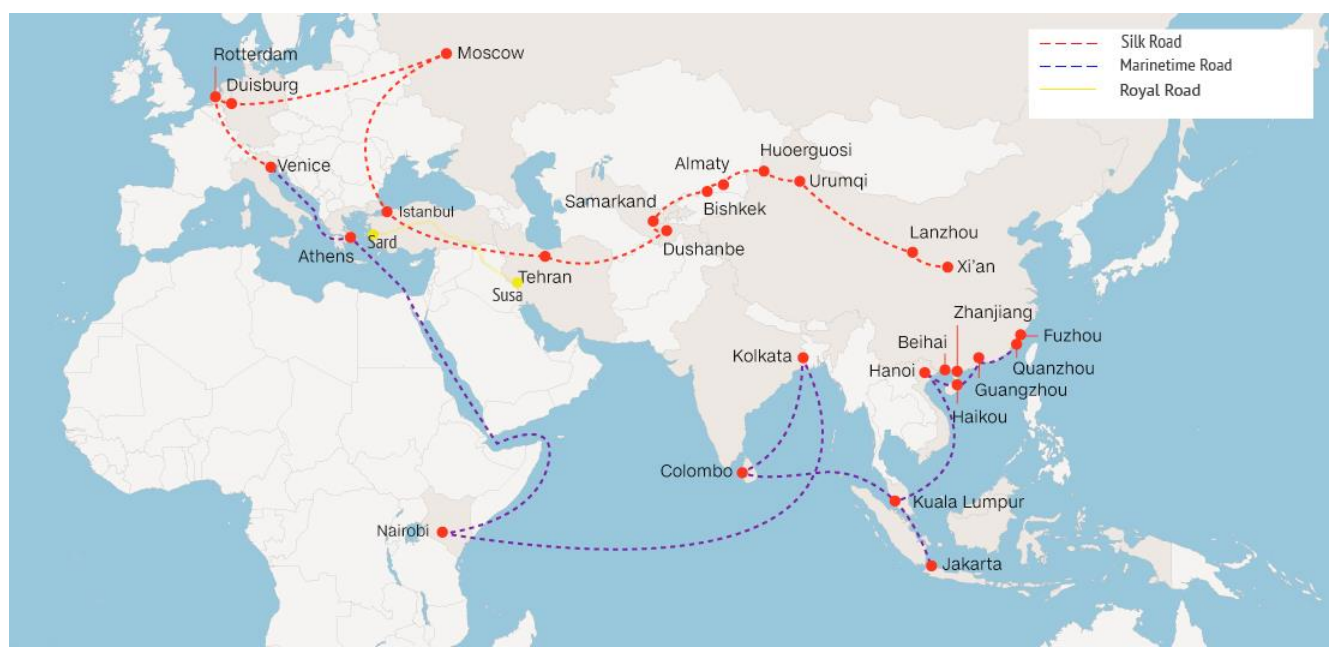

Figure 1. Important Historical Trade Roads

Source: https--financialtribune.com-articles-economy-business-and-markets-64638-iran-s-role-innew-silk-road-emphasized.

\section{Chronological Investigation of Architectural Buildings of Historical Accommodation Structures}

As you can see in every period of trade, there are ways, depending on supply and demand. With the development of roads, cities, states, countries and continents are connected. These travels within the country or between countries have been quite long and difficult. These trips, which last for days and sometimes months, have been made at certain distances to accommodate the caravan's accommodation and needs. Another aim of these structures was to protect caravan's property and life safety. The architectural characteristics of the accommodation structures, plan

2. F. Atasoy, Yükselen Ipekyolu 3 (Ankara: Türk Yurdu Yayınları, 2016), 103.

3. E. Karacan, S. Karacan and Y. Güngör, "Tarihsel Süreç İçinde Konaklama Merkezleri Han ve Kervansarayların Günümüzde İpek Yolu Projesine Dönüşümü," 5.Doğu Akdeniz Turizm Sempozyumu ve I. Uluslararası Doğu Akdeniz Turizm Sempozyumu, Nisan, Doğu Akdeniz Üniversitesi Turizm Fakültesi, KKTC, 2016, 3. 
schemes and functions vary according to various periods and the conditions of the period. $^{4}$

The name Mansiones Veredariorum was given on the commercial roads in the Romans. These structures were built about $75 \mathrm{~km}$ from each other. These structures, from the first official buildings of the Romans, along with functions such as the accommodation of the travelers and the caravans, shelter of the animals as well as provided the road safety of commanders and statesmen. ${ }^{5}$ But they were devastated over time because they were built on a small scale and with weak structure. The Sangarios Bridge in Adapazarı can be an example of the 'Mansiones Veredariorum' structure, which is made up of vaulted spaces on the east side. ${ }^{6}$ (See Figure 2).

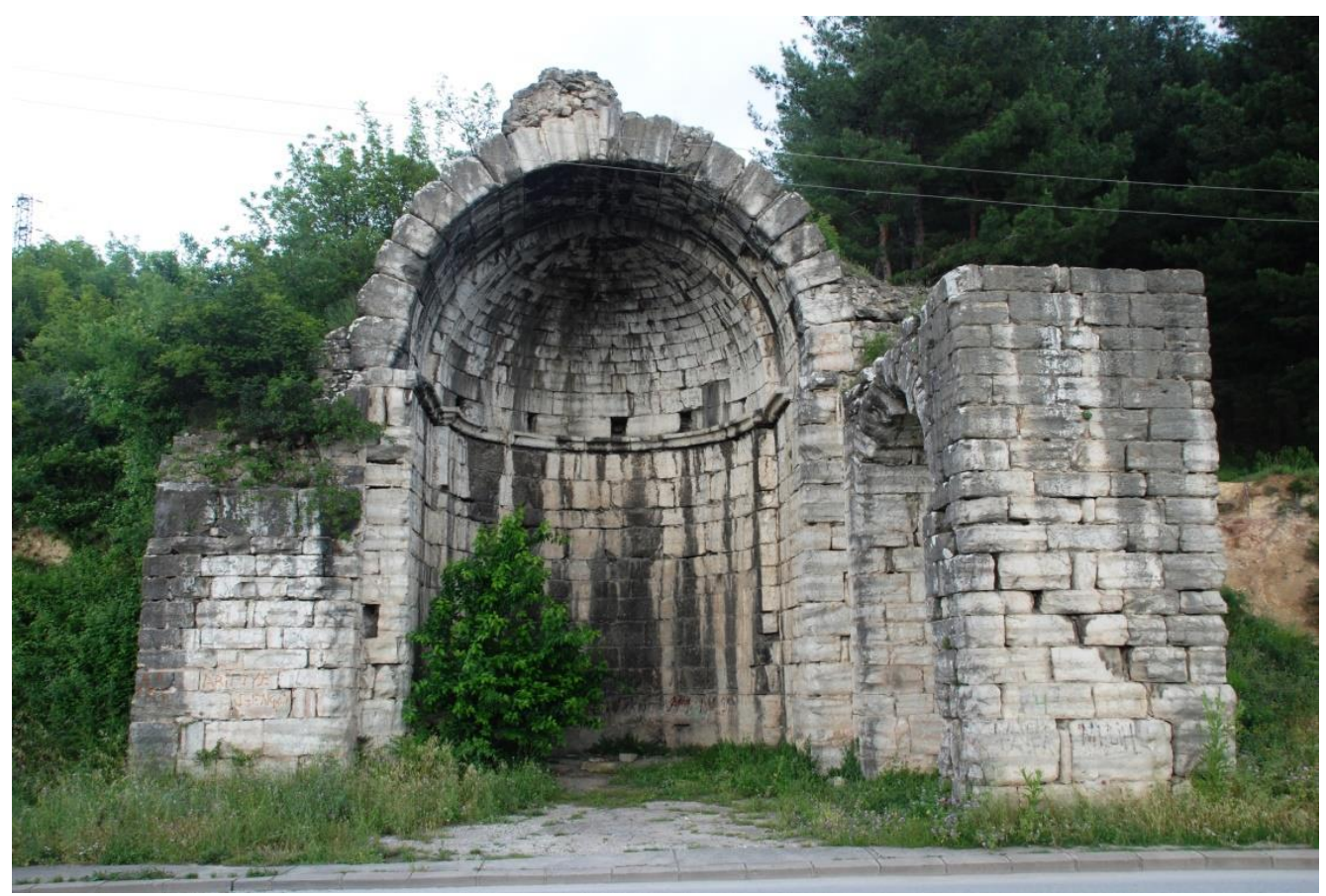

Figure 2. Structure that is Thought of as a House near the Justinianus Bridge, Adapazarl

Source:https://tr.wikipedia.org/wiki/Dosya:Sangarius_Bridge,_Justinyen_K\%C3\%B6pr\%C3\%BCs $\%$ C $3 \%$ BC.JPG.

In areas close to the border during the Roman period especially in the $4^{\text {th }}$ century, castrum for the garrison was built in strategically important regions. Generally, these structures were made in Mesopotamia to defend against Europe from the west, and Persian from the east.

4. A. Baş, Beylikler Dönemi Hanları (SÜ, SBE, 1989), 21.

5. S. Karacan, E. Karacan and Y. Güngör, 'Osmanlı'da Konaklama Hizmeti Veren Yapılardan Gebze Çoban Mustafa Paşa Kervansarayı," III.Disiplinlerarası Turizm Araştırmaları Kongresi Bildiri Kitabı, III.Disiplinlerarası Turizm Araştırmaları Kongresi, 2014, 845.

6. C. Binan, 13. Yüzyll Anadolu Kervansarayları Koruma Ölçütleri üzerine Bir Araştırma. Doktora Tezi (İstanbul: İTÜ Fen Bilimleri Enstitüsü, 1990), 242. 
Some of the castra with axially symmetrical planes in the center were later transformed into settlement centers by the expansion of the boundaries. Towers were built at regular intervals on long facades. ${ }^{7}$ In some sources, it was said that the accommodation was also inspired by Roman's castrum and Sasani's structures. Müller likened the scrolls in the castles to the corners of Iranian caravanserais. Rahmi Hüseyin Ünal mentioned that the Daya Hatun Caravanserai, located in Turkmenistan, reminds of the courtyards of the castles of the porticoed courtyard typology (see Figures 3-4).

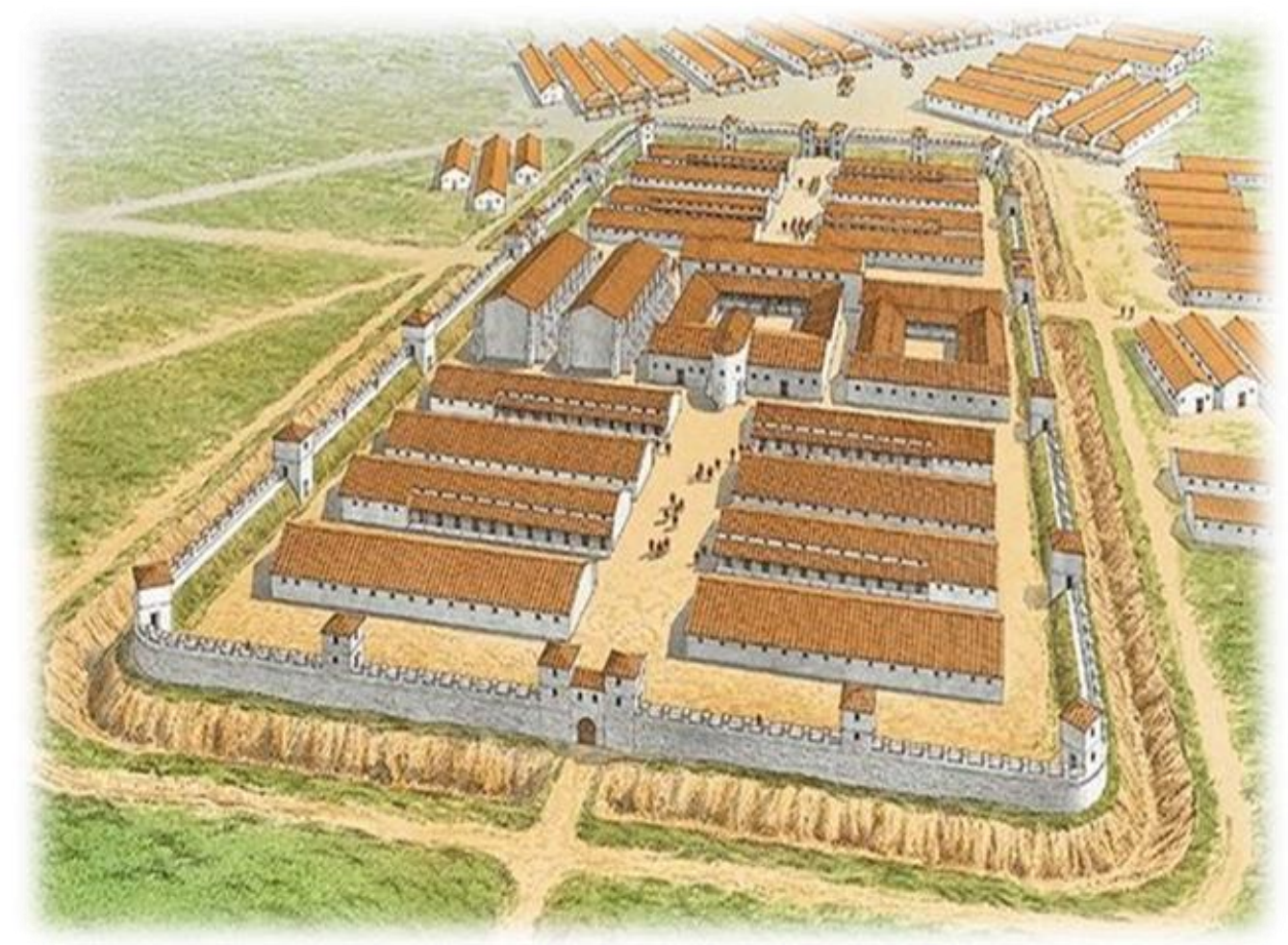

Figure 3. Roman Castra Schematic Visual

Source: https://tr.pinterest.com/pin/290763719686938530/.

7. Türkiye Diyanet Vakfi İslam Araştırmaları Merkezi [Religious Foundation of Turkey.] http://www.islamansiklopedisi.info/dia/ayrmetin.php?idno=240237. Center for Islamic Studies, June 1, 2018. 


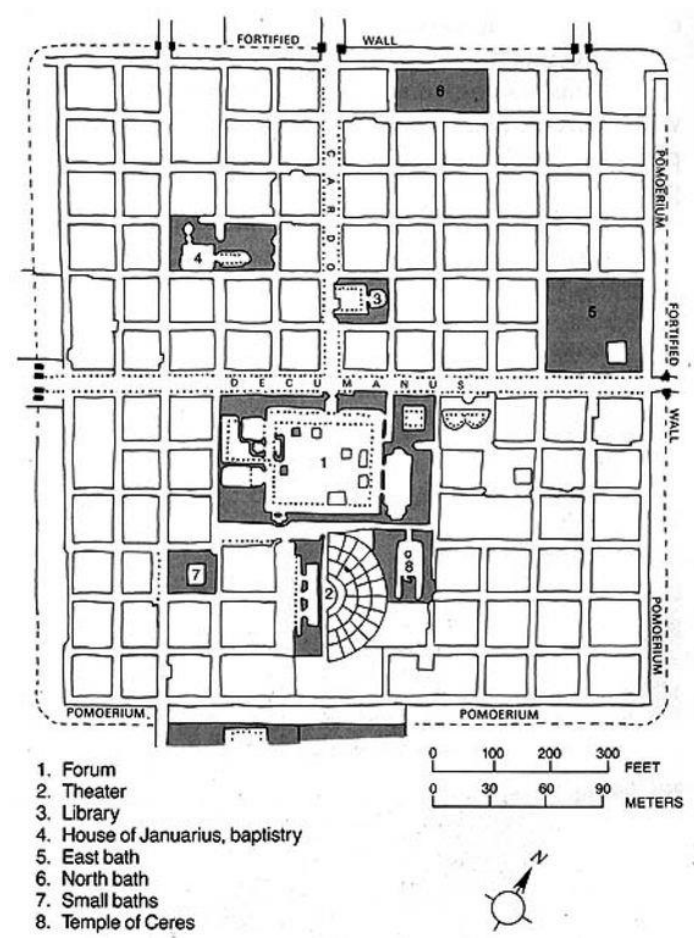

Figure 4. Plan of Roman Castra

Source: https://tr.pinterest.com/pin/574631233679187911/?lp=true.

During the Byzantine era, the accommodation was named 'Xenodochium'. According to Texier, these buildings are the basis for caravanserais and urban khans. ${ }^{8}$ The distance between these accommodation structures located on important and crowded roads under the rule of the Byzantine Empire is about $50 \mathrm{~km}$. ${ }^{9}$ The distance between the constructs takes 8-10 hours on foot. Given the average speed a person will reach on foot; approximately $38-40 \mathrm{~km}$ is the route that the caravan will take in a day. It's a range. The caravans walked one day and stayed in the place they had stayed that night and continued on their way again in the morning. The $50 \mathrm{~km}$ average here is an average expression. The point to be noticed here is that the road condition, geography, season and climate conditions should be considered. According to this, the road can be lengthened or shortened.

Marco Polo mentioned that there were many main roads to the east of Europe in the 8th century and the existence of towns $25-30 \mathrm{~km}$ from each other on these roads. In these towns there are post offices 'jambs' to meet the needs of the passengers. The stations were spacious accommodate the statesmen of the period and even the kings. The needs of these stations have been met by the nearest town and they have said that there are 400 horses ready. Another name for the stations, Jamb, it is of Mongol origin according to Lemke. In Persian, it means the same as 'jan' which means guest house or postal stations. ${ }^{10}$

Historic structures on roads were also found to stay in Mongolian. Mongol

8. Binan, Yüzyll Anadolu Kervansarayları Koruma Ölçütleri üzerine Bir Araştırma, 1990, 243.

9. Karacan, Karacan and Güngör, “Osmanlı'da Konaklama Hizmeti Veren Yapılardan Gebze Çoban Mustafa Paşa Kervansarayı,” 2014, 845.

10. Ibid, 846. 
emperor Ghengiz Khan built postal station on main roads taking samples from Chinese. ${ }^{11}$

In the $7^{\text {th }}$ century B.C. there are 68 khans built between China and the Uyghur State for military purposes. Emel Esin mentioned about the existence of military fortresses and fortresses in order to ensure the safety of the roads in the commercial caravans and to control trader's property. Mustafa Cezar says that some of these inns are made by the Chinese and some by the Turks. ${ }^{12}$ Today is also called the 'Tchan' these structures in China. ${ }^{13}$

Another example of historical accommodation is ribatlar; In the period between 8th-11th century and the strengthening of the Islamic state, it emerges to the north of Central Asia and Africa. Ribat is derived from the root of the RBT in Arabic, which means order, obedience, direction, regulation, control, heartiness, vigilance in the important place. ${ }^{14}$ As you can see, word root is not about accommodation.

Iran, Mesopotamia, Transoxiana (Mā Warā' al- Nahr) lands were seized when Islam spread. It has long and difficult processes to keep this place in its possession. Iran, who had just met with Islam, created control units at the border to protect the authority in Transoxiana and to ensure the safety of the roads. These cities, which are important in terms of military and administration, have been brought in by experienced and certain members of the family who dominate the region. ${ }^{15}$ It is understood from these expressions that the ribats were built at the border of the military and religious center in the early days of Islam. Many fortresses were built on the military road where the ribats were located or a settlement center was built. Especially in the structure of the castle, it goes back to Merve Part Sassanian period. Although there is a difference in functioning between these qualities and ribats, the space organisms resemble each other. Some of the remains of the Sassanian period were also used for defensive purposes during the period when the region was Islamic. One of these remains is Çilburç Castle, which was used in the Seljuk Period. ${ }^{16}$ This structure has not reached to daylight.

With the strengthening of the Islamic state, new lands were seized in Central Asia. As the surface area grows, new borders have formed and new defenses have been built on these borders. In particular, the number of defense structures called ribat in the Transoxiana region has increased. According to Ibn Hallikan, 10,000 ribats were built in the Transoxiana region. After expanding the borders, the bibs remaining in the inner parts have lost the castle function and have been used with different functions such as accommodation and trade. ${ }^{17}$

The general plans of the Ribat are composed of spaces that meet needs such

11. Ibid.

12. Baş, Beylikler Dönemi Hanları, 1989, 21.

13. Karacan, Karacan, Güngör, "Osmanlı'da Konaklama Hizmeti Veren Yapılardan Gebze Çoban Mustafa Paşa Kervansaray1,” 2014, 846.

14. S. Sönmez, "Ortaçağ Türk ve İslam Dünyasında Kervansaraylar (Hanlar - Ribatlar,)" Kâzım Karabekir Eğitim Fakültesi Dergisi, Erzurum (2007): 274.

15. Ibid, 275; O. Turan, "Selçuk Kervansarayları," T.T.K. Belleten X/39 (1946).

16. Atasoy, Yükselen Ípekyolu 3, 2016, 119; H. R. Ünal, "Antalya-Korkuteli Kervan Yolu Üzerinde Bilinmeyen Üç Han,” Sanat Tarihi Dergisi XIX/1 (2010): 61-62.

17. Baş, Beylikler Dönemi Hanları, 1989, 22. 
as warehouses, stables, mosques, shaped around a courtyard in the middle. Another important feature of the Ribats is the spectator lifts, which are also used as minarets. ${ }^{18}$ When viewed from the outside, it is surrounded by high walls, providing a strong appearance. The soldiers used to serve as defense structures and were prepared for the campaigns.

The oldest biblical example that came up to the sun is the building remains in Timriz (Uzbekistan), also known as the caravanserai, dating to the $8^{\text {th }}$ century. It forms a massive mass with the masonry walls and reinforcements at its corners. Sousse Ribat, one of the oldest examples, was built in 821 AD. It is important for the understanding of the ribat architecture that the plan and the architectural features of the building are now available for reading. It has a rectangular plan and there are towers in the middle of the walls at the corners of the structure (see Figures 5-7). It is two floors and there is no visual communication outside the window of masjid. ${ }^{19}$

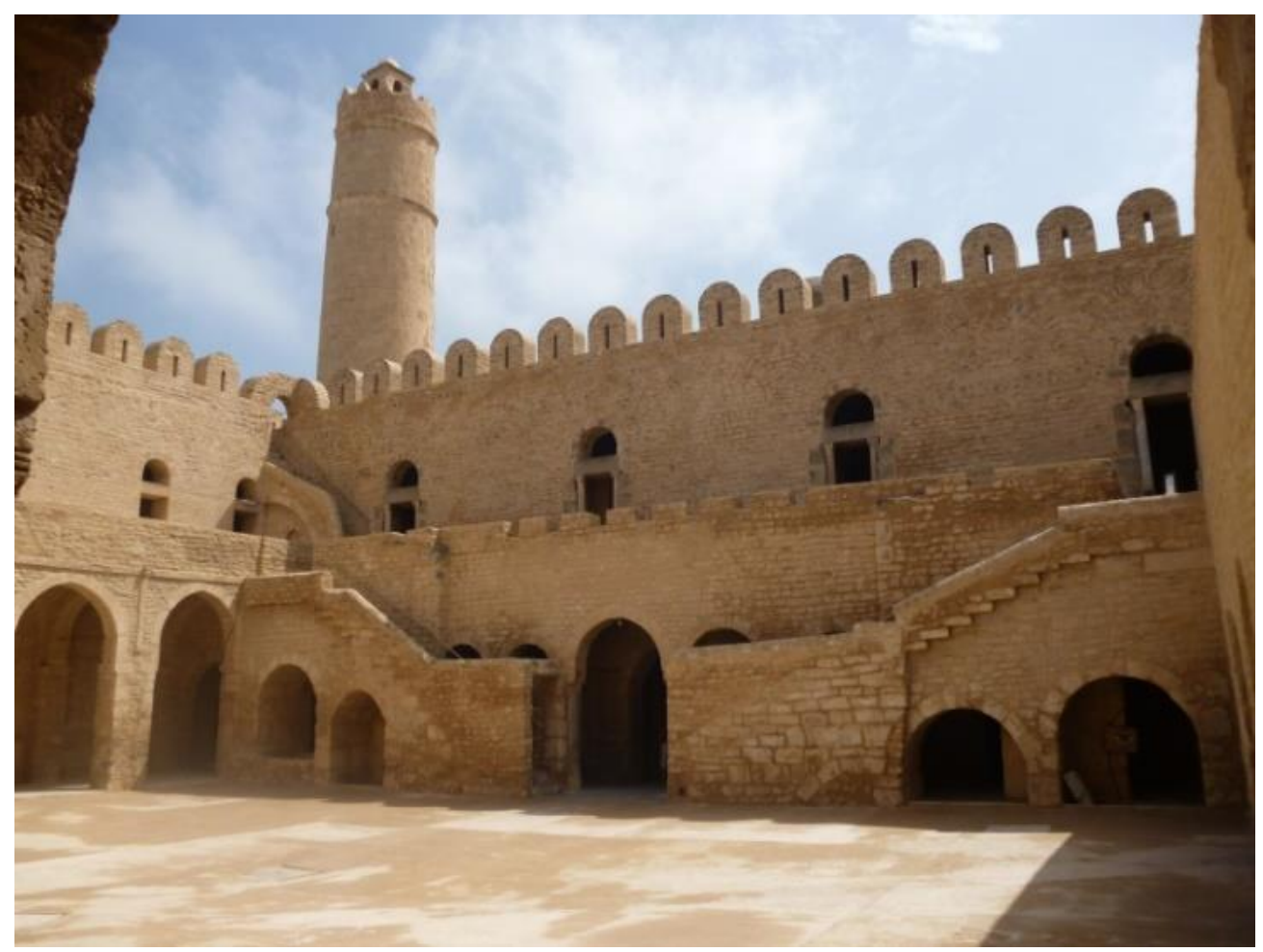

Figure 5. Sousse Ribat, Tunisia Courtyard and Tower

Source: https://en.wikipedia.org/wiki/Ribat_of_Sousse\#/media/File:Medina_of_Sousse-130323.jpg.

18. Ibid, 23.

19. Ibid. 


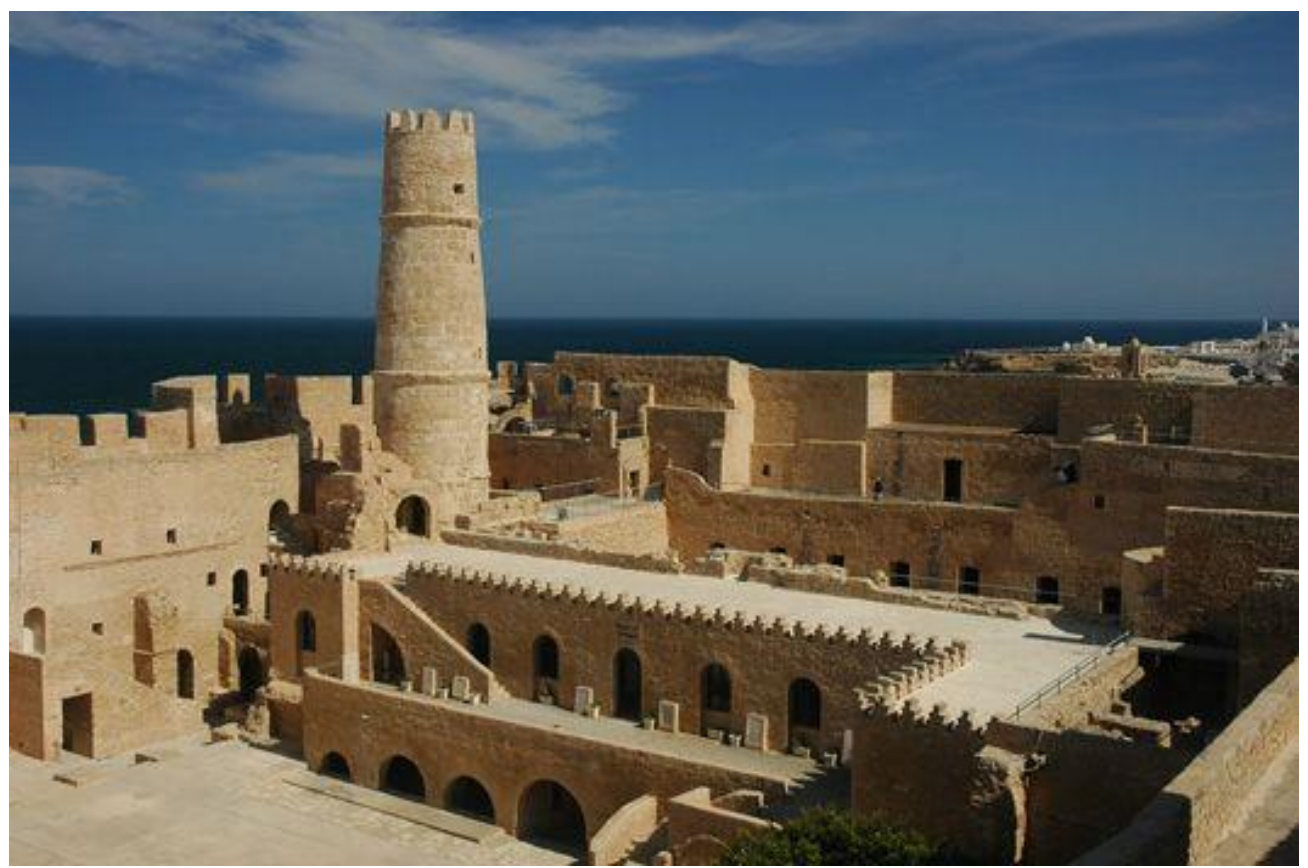

Figure 6. Sousse Ribat, Tunisia General View

Source: https://tr.pinterest.com/pin/488570259551849184/?lp=true.

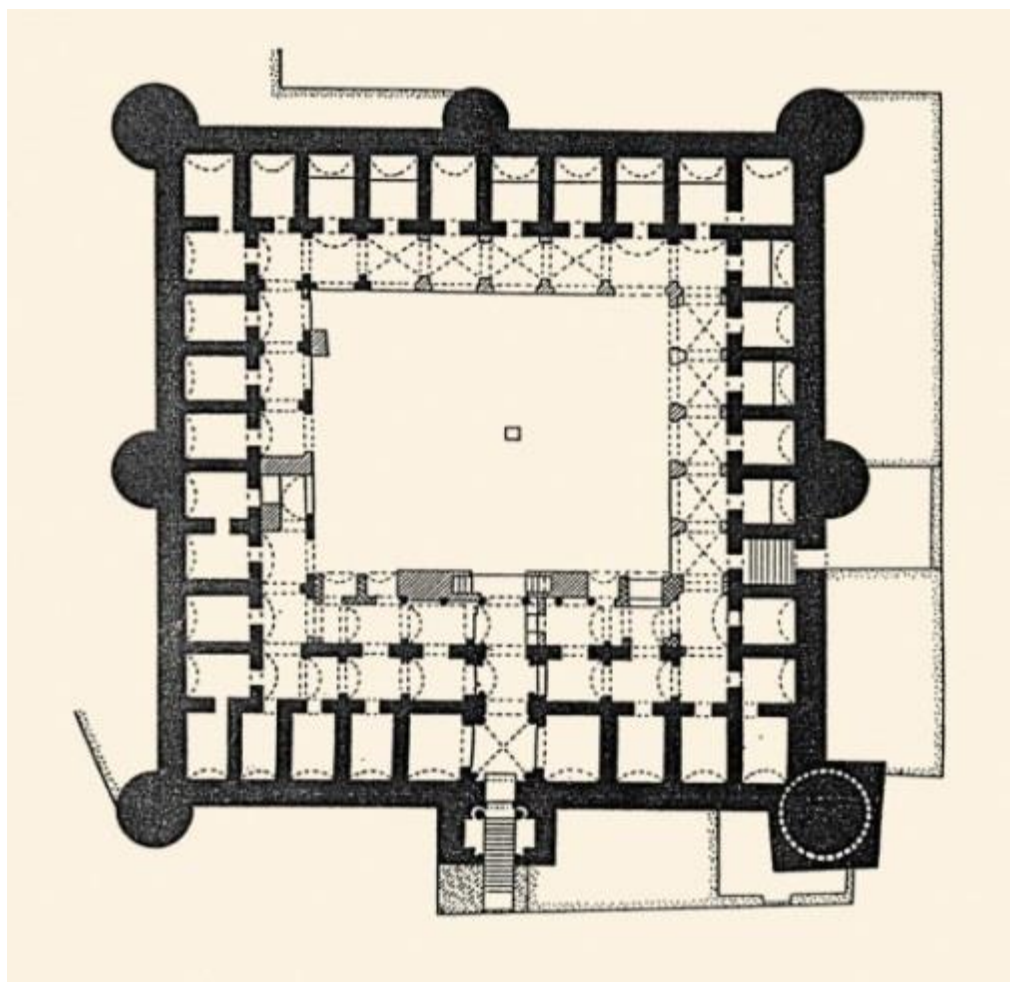

Figure 7. Sousse Ribat, Tunisia Plan

Source: https-_islamansiklopedisi.org.tr_suse-ribati.

In the $8^{\text {th }}$ century, the functions of the ribats that built on the border with the defense purpose have changed with the spread of Islam and the expansion of the 
boundaries of the Arabs, in the $10^{\text {th }}$ century, the trade routes and main road network in the Transoxiana region are now covered by the country's land. The defending ribats became a meeting place for accommodation stations or religious meetings. This is also the case for the definitions of lodge, 'zaviya'* , fortress. $^{20}$

The Turks were usually influenced by the culture and civilization of the Arab geography by meeting with Islam and gradually accepting Muslims. There have been many architectural influences. One of them has also been ribats that continuing the accommodation function. In the first Muslim Turkish states, khans and caravanserais were called ribat. The first ribat in Turks were built during the Karahanlı's and Gazneli's era. The earliest example of ribat is Ribat-1 Mahi, which was built by Gazneli Mahmud between 1019-1020. The other one is Ribat-1 Melik, which was built between the years of 1079-1080 in Karahanlı's period ${ }^{21}$ (see Figures 8-9).

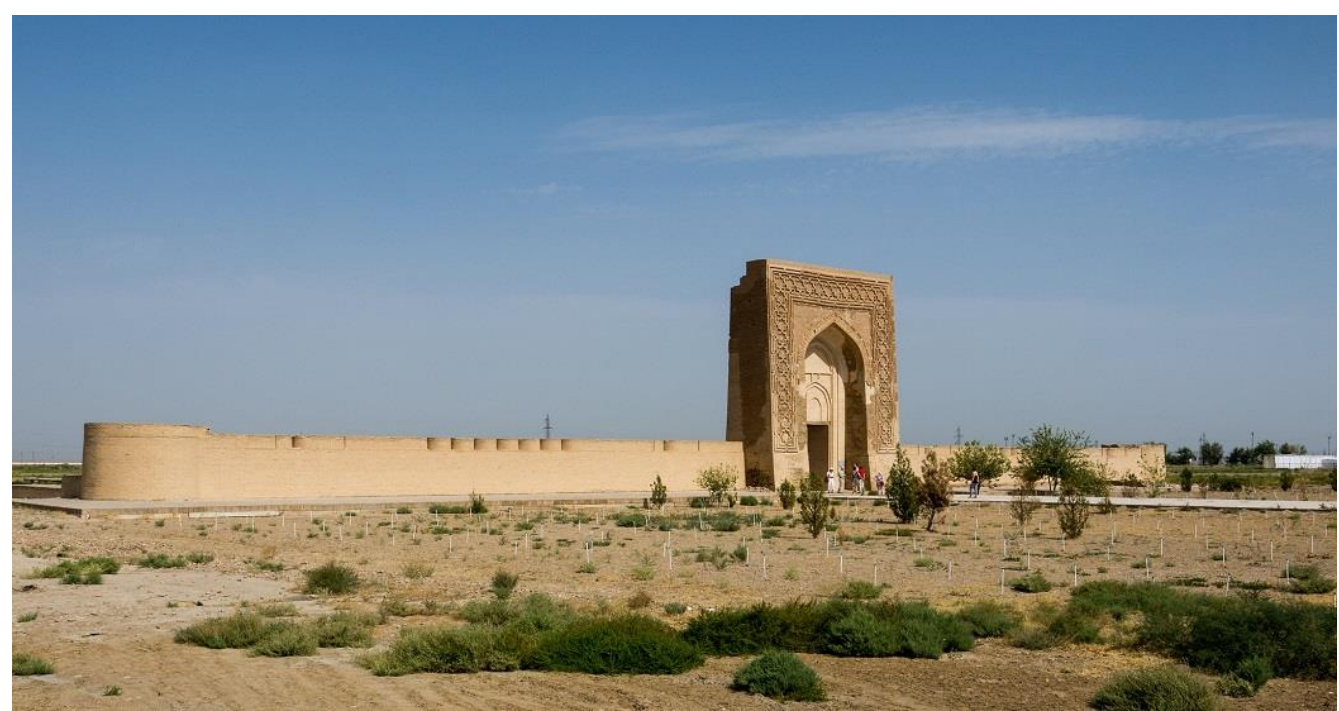

Figure 8. Ribat-ı Malik General View

Source: https://okuryazarim.com/ribat-i-melik-kervansarayi/.

20. Binan, 13. Yüzyıl Anadolu Kervansarayları Koruma Ölçütleri üzerine Bir Araştırma, 1990, 243.

21. Baş, Beylikler Dönemi Hanları, 1989, 23. *Zaviya: Place of Sufism Education. 


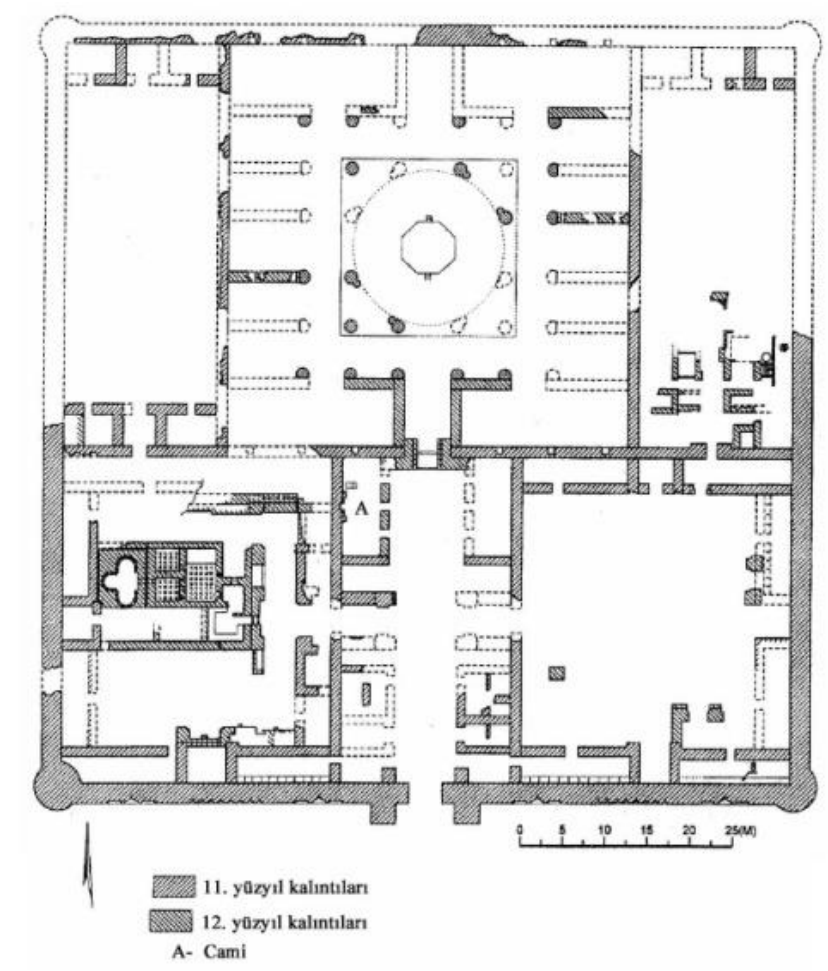

Figure 9. Ribat-ı Malik Plan

Source: https://okuryazarim.com/ribat-i-melik-kervansarayi/.

\section{Seljuk Period in Anatolia and Anatolian Seljuk Caravanserais}

By the arrival of the Turks to Anatolia, Turks took the place of the Arabs in the battle with Byzantium. By the end of the $11^{\text {th }}$ century, the Byzantine was weakened. In Anatolia commercial life has lost its former vitality and roads have been used for military purposes. ${ }^{22}$

The demographic and political structure of Anatolia has begun to change and it has faced more with Byzantine and European Turks. After Malazgirt Turks started to come to Anatolia (see Figures 9-10). Anatolian roads deserted with the use of the sea route over Egypt in the centuries have been revitalized with the provision of road safety. ${ }^{23}$

Seljuk State knows the importance of trade and trade routes of Anatolia, Seljuks gave importance to the security and development of the road. Black Sea and the new ports and ports in the Mediterranean by establishing the city of trade, Anatolia, the interior has allowed them to enter. Caravan trade is not only in the form of taking and leaving goods, but in every point of residence there is a commercial activity and a development in the places where it is hosted enriches

22. Binan, 13. Yüzyll Anadolu Kervansarayları Koruma Ölçütleri üzerine Bir Araştırma, 1990, 14.

23. Baş, Beylikler Dönemi Hanları, 1989, 8. 
Anatolian cities. $^{24}$

A lot of work has been done to keep the commercial life alive and to ensure road safety. At the beginning of the $13^{\text {th }}$ century Antalya was taken over by Giyaseddin Keyhüsrev and worked to become a free trade center. Faced with the low cost of maritime trade, many conveniences have been provided to direct traders to land trade and to stimulate land trade and to encourage local and foreign merchants. The deal was signed with the Venetians, the main trading state, and the taxes in the ports were removed. Trade agreements with foreign states have been made. ${ }^{25}$

When we look at the existing road route during Anatolian Seljuk period; with Konya being the capital city we see that the road network started from İstanbul and left Konya in the southeast and northeast direction. One of these roads reached the Antakya from the Gülek Passing by going south. The other way was to go from Kayseri, Sivas, Erzurum and then Iran to the north-east of Konya. ${ }^{26}$

During the Seljuk period, the northern southern line in Anatolia also came from the most important road routes. Especially after the $13^{\text {th }}$ century, this route, which has increased in importance, has been connected to Trabzon through the Black Sea via Sivas and Malatya, a road network starting from Baghdad and Aleppo. Sivas was the intersection of the roads leading to these three regions and the 11th-13th. It has become an important trade center for centuries.

The transit route from here to Iran, where Trabzon is an important port in the $12^{\text {th }}$ and $13^{\text {th }}$ centuries, has directed the Seljuks to the Black Sea ports. The Seljuks wanted to seize the ports of Sinop and Samsun and to pass the commercial road network from Anatolia. Sinop was seized in 1214 to connect the Black Sea ports to Anatolia. With the Armenian kingdom in Cilicia threatening Aleppo, 1214 Aleppo flights were made and the road was opened to safe traffic. Located between Kayseri and Malatya, 'Yabunlu Bazaar' is an international fair. This shows how active Anatolian trade is in that period. ${ }^{27}$

With the seizure of Sinop and Alanya, the road to Iran from Alanya, Antalya, Konya, Aksaray, Kayseri, Sivas, Erzincan and Erzurum entered into Seljuk control. The same road separates south from Sivas; Malatya, Diyarbakir, Mardin, Mosul to Baghdad and Basra. Another road network starting from Istanbul was reached from Izmit, Iznik, Eskisehir, Aksehir, Konya, Ulukisla, Adana, Aleppo, and Damascus to Egypt. As you can see; there are many road networks in the Anatolian lands during the Anatolian Seljuk period. The main road network has been preserved by the topographic and economic conditions; to build trade, caravans have built many caravanserais, inns and ribs to provide road safety and accommodation (see Figure 10.) ${ }^{28}$

24. Binan, 13. Yüzyll Anadolu Kervansarayları Koruma Ölçütleri üzerine Bir Araştrrma, 1990,15 .

25. Ibid, 18.

26. Çetin, E., "Franz Taeschner'in Muhtelif Devirlerde Anadolu'nun Yolları Ve Cihan Münakalatına Nazaran Vaziyeti İSsimli Eseri ÜzeriNe Notlar,” 2014.

27. Binan, 13. Yüzyll Anadolu Kervansarayları Koruma Ölçütleri üzerine Bir Araştırma, $1990,16$.

28. A. Eskikurt, "Ortaçağ Anadolu Ticaret Yolları," Sosyal Bilimler Enstitüsü Dergisi, Muğla (2014): 33, 21. 


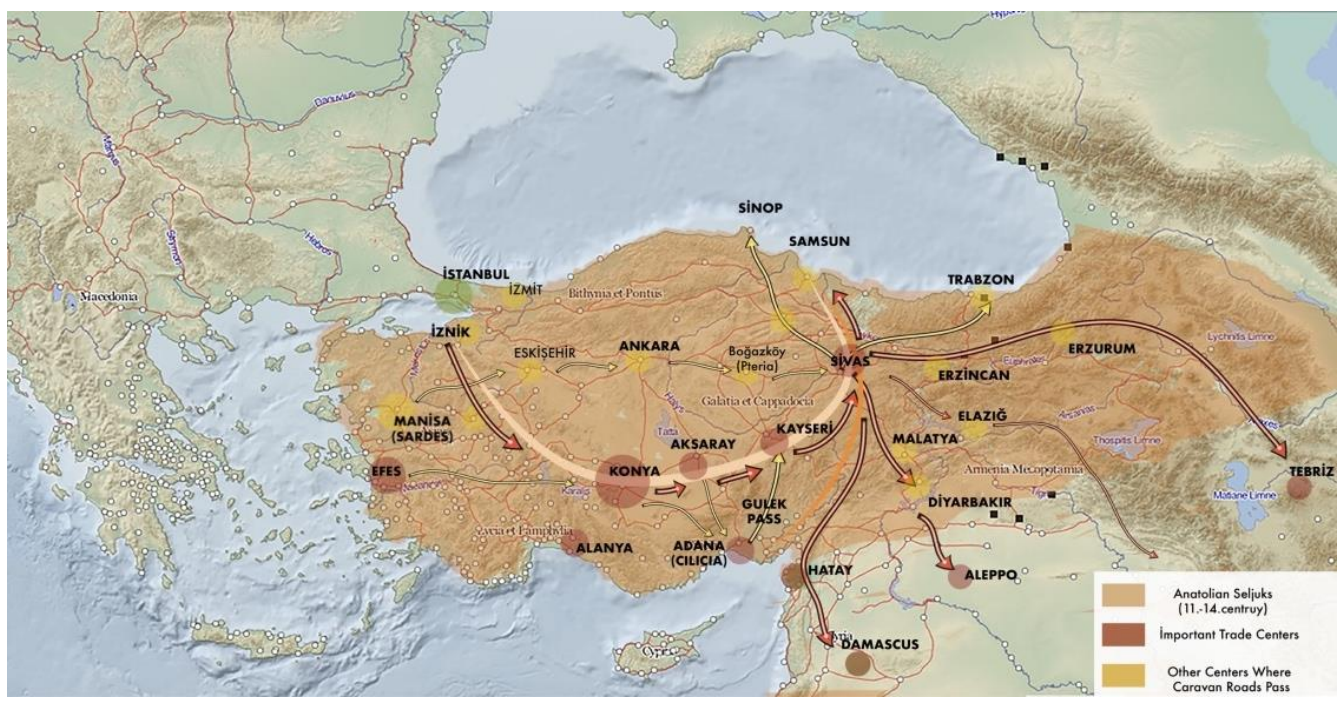

Figure 13. Anatolian Roads in the Seljuk Period

Source: Darendeli, 2018.

As Anatolia has become a transit center in highway trade, cultural exchange has been experienced besides goods and services. The architectural characteristics of various civilizations from Asia to Iran have changed according to the topographic, climatic and administrative conditions of Anatolia and created a unique model. The Seljuks built their own unique culture and civilization with their administrative structures strengthened by their own experience. They have found inventive works in architecture and art. Caravansaries were also the most important examples of this inventive architect (see Figure 11).

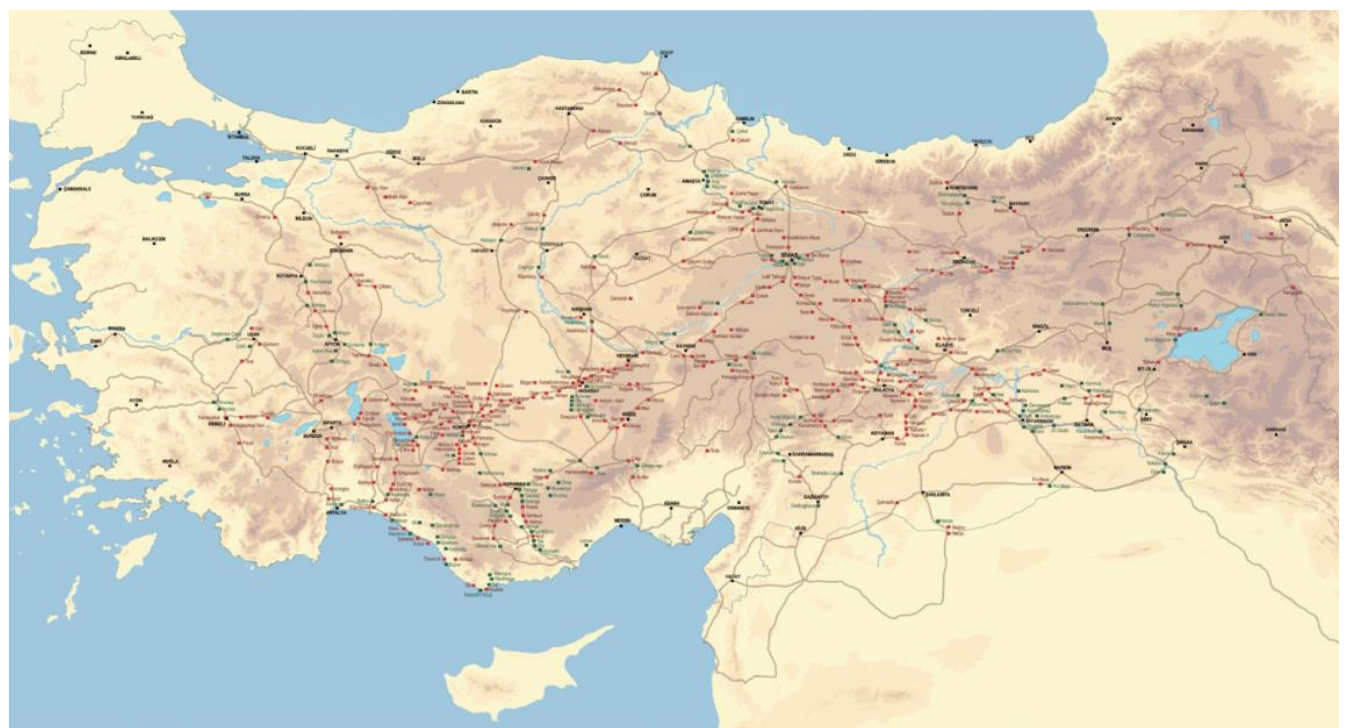

Figure 11. Anatolian Seljuk Caravanserais on Trade Roads

Source: https://www.cekulvakfi.org.tr/haber/ipek-yolu-kultur-yolu-haritasi.

When we look at the origin of the caravanserai term, it is understood that the word "karban" is derived from Persian. "Karban" is the place where the passengers 
are staying and staying overnight; "Karbanserai" means the place where the trader works. Over time this expression has turned into a "caravanserai". It is a structure that allows travelers and caravans to travel from one settlement to another, to meet their various needs, to connect their animals, and to secure the passengers safely until the sunrise the next day.

Anatolian Seljukian period caravanserais and khans, some of the inscriptions (stone tablets) on the name of the building was seen as ribat. This is a sign that the concept of caravanserai and inn is the continuation of ribats. ${ }^{29}$ But in plan design, materials and functions; there have been changes depending on period and geography. Built in Iran and Central Asia between the $10^{\text {th }}$ and $13^{\text {th }}$ centuries, the khans are generally shaped around a courtyard. In the first Turkish states, ribates are generally square or rectangular in plan. It was from the courtyard and the courtyard in the middle of the revolving places. On the four sides, there are "iwan (eyvan)" in the middle. This form has been the continuation of a tradition of home from Central Asia. The building material used is adobe, brick or stone depending on the region. ${ }^{30}$ Anatolian Seljuk caravanserai are very rich in terms of plan schematics. There are only examples of courtyard caravanserai which is the continuation of tradition coming from Central Asia. In addition to this, there are only indoor caravanserai examples which are made according to geographical and economic conditions. In more advanced plan examples, there is a closed space and a courtyard that opens to it. ${ }^{31}$

\section{Foundation Administration and Operation in Anatolian Seljuks Caravanserai}

When you look at the social and cultural structure of the Seljuks, there are two important institutions besides the state structure. These are 'ahilik' and "foundation (waqf)"organizations. Leaders of the state could establish themselves a foundation or donated to the foundation. Depending on the organization of the foundation, more activities were carried out in the country. Khans, caravanserais, bridges, hospitals and madrasahs have been built. Buildings such as mosques, hospitals, caravanserais which are connected to the foundations make their own administration, managed by incomes and donations, and the foundations are not traded. $^{32}$ In the caravanserais connected to the foundation system, the three day expenses of the Muslims and non-Muslims were covered by the foundation. ${ }^{33}$

In Anatolia in the Ottoman period, the road network has changed and some roads have lost importance and deserted. The caravanserais on these roads have been abandoned. Over time, they have been devastated by weather conditions, human-induced causes and non-use. The number of caravanserais in Anatolia that have remained in rural areas and are in ruins is quite high. The most important

29. Baş, Beylikler Dönemi Hanları, 1989, 24.

30. Ibid, 23. 1990, 244.

31. Binan, 13. Yüzyıl Anadolu Kervansarayları Koruma Ölçütleri üzerine Bir Araştırma,

32. Karacan, Karacan, Güngör, "Osmanlı'da Konaklama Hizmeti Veren Yapılardan Gebze Çoban Mustafa Paşa Kervansarayı,” 2014, 846.

33. T. Osman, "Selçuklu Kervansarayları," TTK Belleten X/39 (1946): 471-496. 
resources that we can reach the information about these structures are 'foundations'.

As we have seen in Romans and Byzantines, the distance between caravanserais in the Anatolian Seljuks is the distance a caravan can take in a day. Approximately $35-40 \mathrm{~km}$. It is a "manzil". Therefore, the caravanserais are also called the manzil khans. ${ }^{34}$

The city khans are different from the manzil khans and are in harmony with the urban texture. It is usually commercial function. Because cities are surrounded by ramparts and safety is partly provided, there is no need for a defense like in the manzil khans. It usually consists of rows of rooms lined up two floors around a courtyard. The ground floor is used for stables, warehouses and commercial purposes, and the first floors are used for accommodation purposes. ${ }^{35}$

Many khans and caravanserais were built on the roads for accommodation and commerical purposes. Especially in the time of I. Alaeddin Keykubad, the importance of zoning activities was given. Aksaray and Tuzhisar Sultankhan, the most spectacular caravanserais of Anatolia, were built during this period. ${ }^{36}$

\section{Space Organization and Architectural Features of the Anatolian Seljuk Caravanserais}

The Anatolian Seljuk caravanserais are a continuation of Central Asia and have their own architectural solutions. In Anatolian Selçuklu caravanserais, space fiction constitutes two main elements. The courtyards are covered with courtyards. These also vary within themselves. Courtyards; open and semi open spaces. In the closed areas, no parting is done. The function of the room used is understood from the elevations used and the shapes used to serve humans or animals. ${ }^{37}$

The caravanserai built during the Anatolian Seljuk period is a castle view from the outside. The inside, however, is quite lively both commercially and socially. There are places such as overnight accommodation, mescit, hamam, kitchen, infirmary, barn and fountain which will respond to the needs of the caravans. $^{38}$

The location of the caravanserais may differ according to the geography, who made it, and the period. We can say that the enclosed area exists in all. It is understood from the presence of two monumental portals in the structure that the courtyard was later enclosed in courtyard caravansaray. Probably first a closed section was made, a courtyard was made in front of the entrance door in case of improvement of conditions or necessity of people. ${ }^{39}$

Caravanserais in Anatolia are also known by their names of father (bâni). The khan built by the sultans, "Sultankhan" name is given. It is more spectacular and more monumental than the other caravanserais. The Aksaray-Konya road is

34. Baş, Beylikler Dönemi Hanları, 1989, 25.

35. Ibid, 26.

36. Ibid, 10.

37. Binan, 13. Yüzyıl Anadolu Kervansarayları Koruma Ölçütleri üzerine Bir Araştırma, 1990, 246.

38. Baş, Beylikler Dönemi Hanları, 1989, 24.

39. Binan, 13. Yüzyıl Anadolu Kervansarayları Koruma Ölçütleri üzerine Bir Araştırma, 1990, 247. 
located on Aksaray Sultankhan and Kayseri-Sivas road is located on Tuzhisarı Sultankhan. The general architectural structure of these two "Sultankhan" was also similar. The courtyard is entered and the enclosed section is passed through the portico units turning around the courtyard. The closed section is not partitioned here as in the more modest examples, but the functional differences are determined by the heights formed in the ground. ${ }^{40}$

Various plan schemes have emerged according to the person, concentration, economic conditions, and climate of the caravanserais. Erdmann collects caravanserais under three main headings. Ayşıl Tikel Yavuz also adds a special typology of the focal points of khans. ${ }^{41}$ In this study, examine caravanserais in 4 main headings according to this information.

Plan Typology

1. Closed Space Planned Caravanserais

2. Closed Space and Courtyard Planned Caravanserais

3. Courtyard Planned Caravanserais

4. Concentric Planned Caravanserais

Closed space planned caravanserais

This plan typology which consists only of indoor space is often unfinished before the courtyards are completed. For this reason it only consists of closed space. There are also khans designed as closed spaces during the first construction period. An example of this is Şarapsa Khan. Between the years 1236-1246 was built during the Sultan II. Giyaseddin Kevhusrev period. ${ }^{42}$ The khan on AlanyaAntalya is also known as "Şarapsa", "Şarabsa", "Sarafşa" or "Sarafsa". The structure consists of a single closed space with a rectangular plan (see Figure 12). This enclosed space is covered with a pointed barrel vault extending in the eastwest direction. A masjid was added to the east side of the structure in the northsouth direction.

40. Ibid, 246.

41. Ibid, 247.

42. Binan, 13. Yüzyll Anadolu Kervansarayları Koruma Ölçütleri üzerine Bir Araştırma, 1990, 215. 


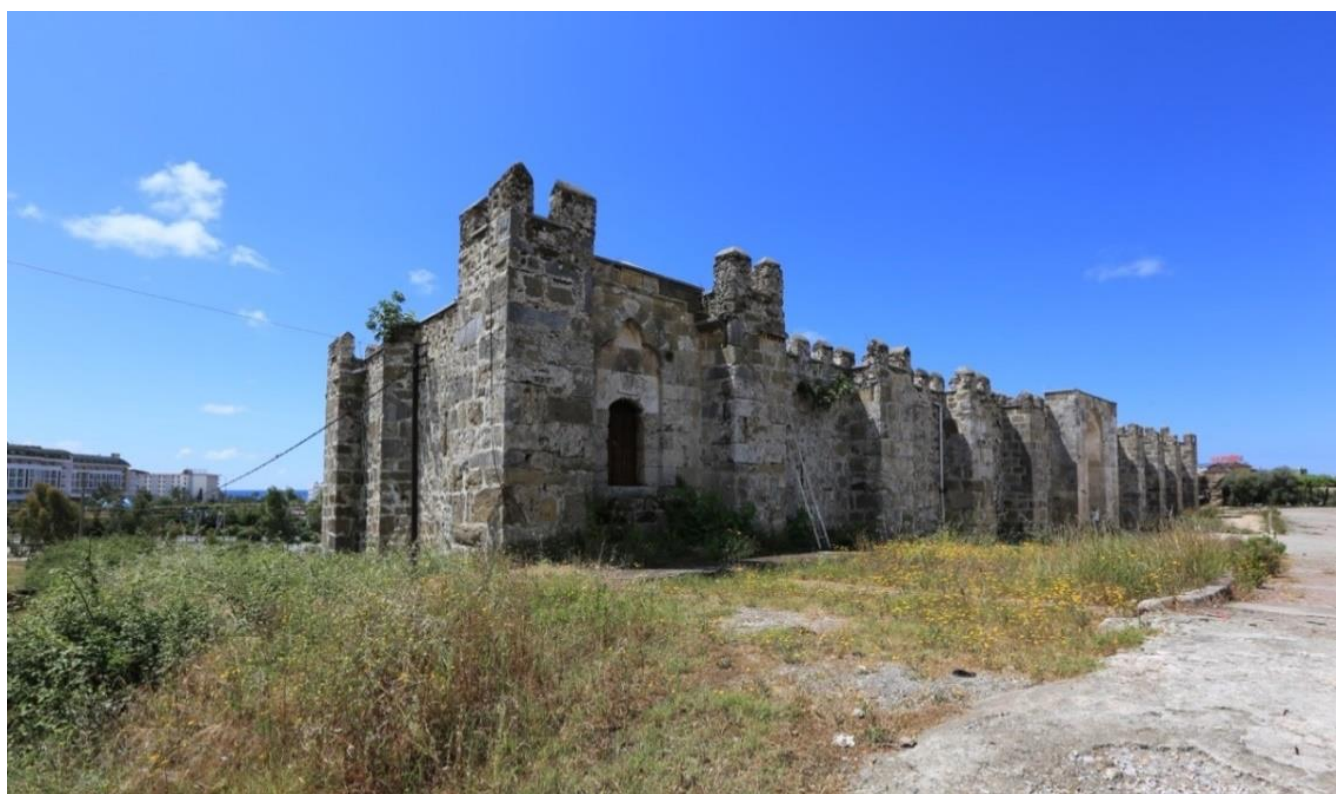

Figure 12. Şarapsa Khan(Antalya) General View

Source: https-//www.semerkanddanbosnaya.com/portfolio/sarapsa-han/.jpg.

The upper cover of the masjid is a barrel vault extending in a north south direction. Structure, with the added mescit portion covers an area of approximately $11.50 \times 71.00 \mathrm{~m}$. The structure which has a long rectangular plan has rectangular shaped struts at equidistant distances on the north and south facades structure having a long rectangular plan is situated equidistant to each other in a rectangular form struts. The eastern and western facades are supported in the middle by triangles in the form of struts. There is a portal on the northern edge of the building that opens into the interior. (See Figure 19) All the facade spinning dykes at the level of the roof gave the building a castle view. ${ }^{43}$ (See Figures 13-16).

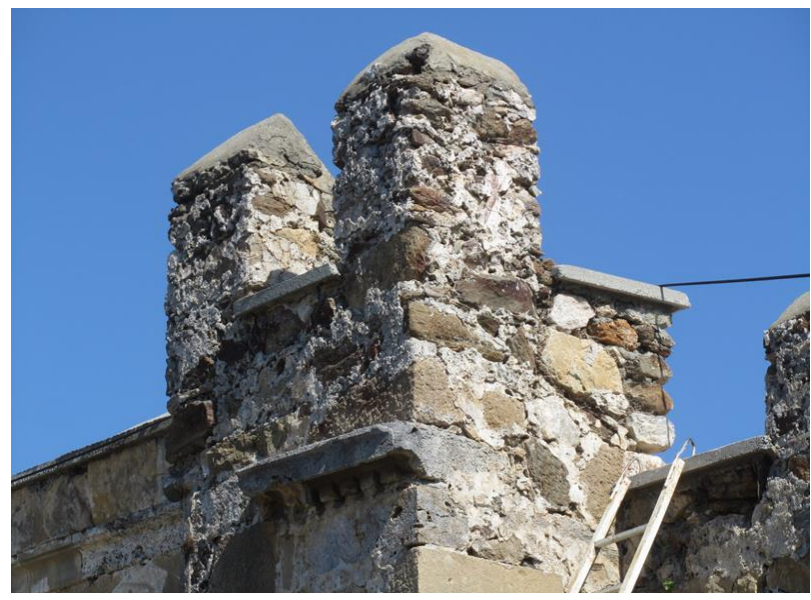

Figure 13. Şarapsa Khan Detail

Source: http://www.anadoluselcuklumimarisi.com/picture/388_18_14.jpg.

43. H. Acun, Anadolu Selçuklu Kervansarayları (Ankara: T.C. Kültür Bakanlığı Yayınları, 2007), 393. 


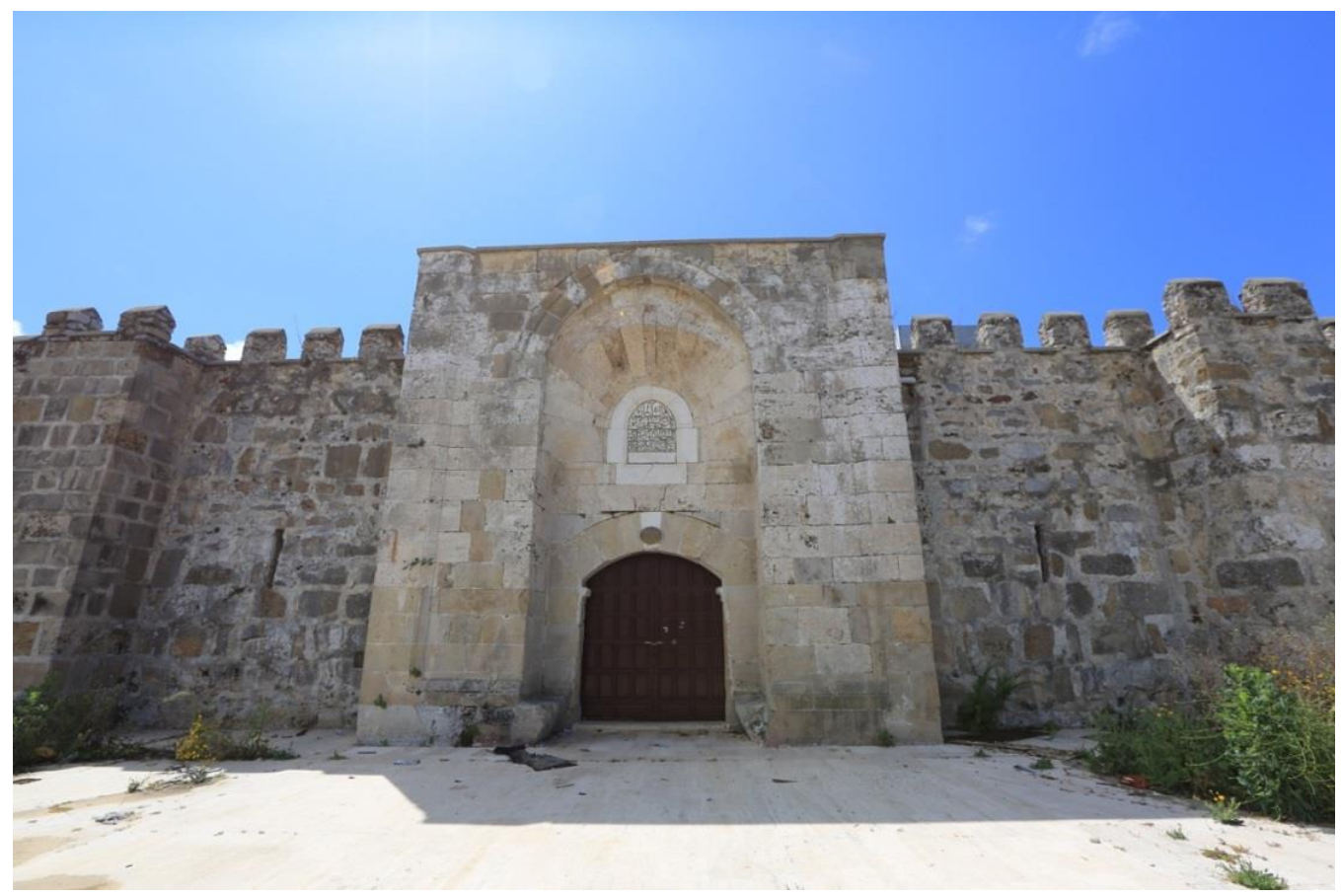

Figure 14. Şarapsa Khan Portal

Source: https-//www.semerkanddanbosnaya.com/portfolio/sarapsa-han/.jpg.

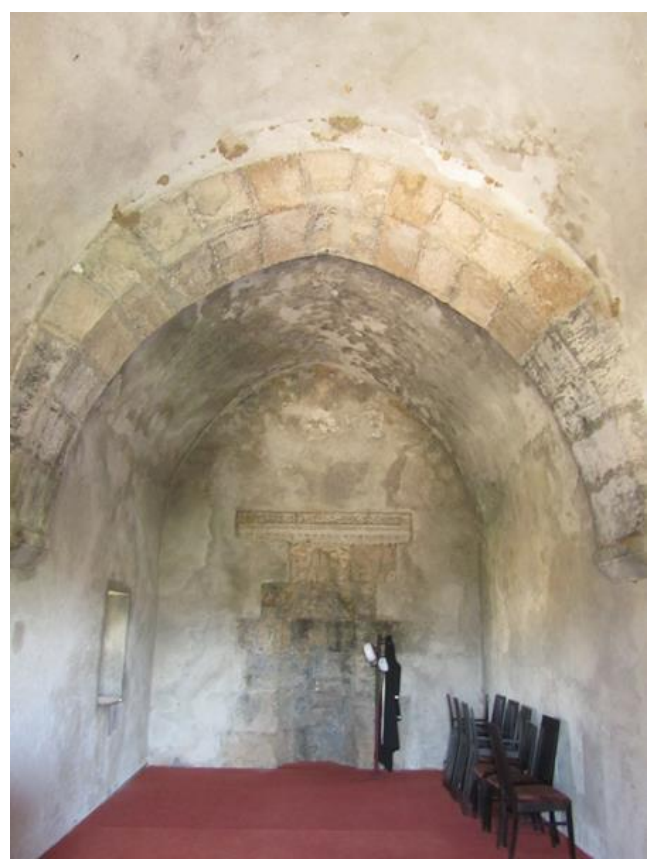

Figure 15. Şarapsa Khan Masjid

Source: http://www.anadoluselcuklumimarisi.com/picture/388_18_17.jpg.

In the walls of the building there are rough cut stone at the crown of the masjid and the khan, and rubble stone used in other parts (see Figure 16). The inside of the wall coverings is filled with rubble and formed a very thick layer. 
Wall thicknesses are approximately $1.25-1.50$ meters. $^{44}$

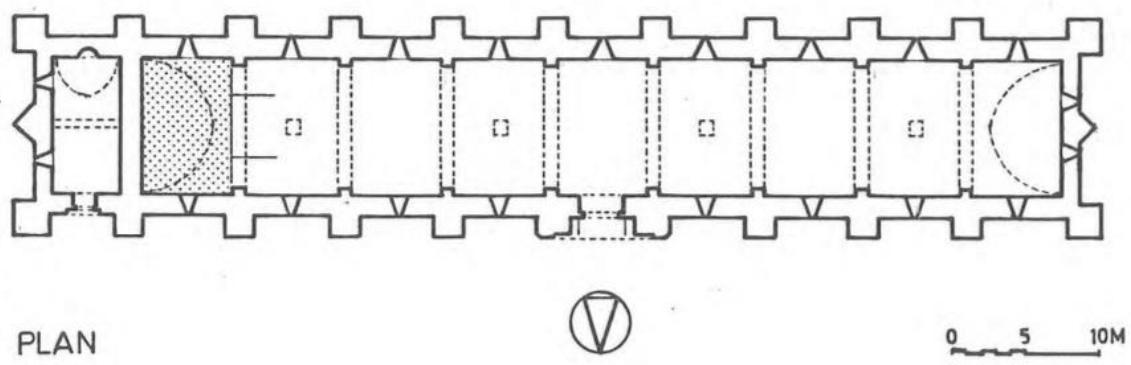

Figure 16. Şarapsa Khan Plan

Source: Binan, C., (1990). 13. Yüzyıl Anadolu Kervansarayları Koruma Ölçütleri üzerine Bir Araştırma, Doktora Tezi, İTÜ Fen Bilimleri Enstitüsü, İstanbul, 223).

Closed space and courtyard planned caravanserais

We can separate subheadings according to vault layouts and space sizes. This plan typology is generally used in Central Anatolia. First, an enclosed space was built and then the courtyard was added due to the improvement of the economic situation and conditions or the need. There are many examples of this plan typology. Aksaray Sultankhan, one of the biggest and most spectacular caravanserai in Anatolia, is also an example of this construction.

Aksaray - Konya on the way to give the name of the Sultankhan district is the first construction date of the building is 1229. It was built by I. Alaaddin Keykubat. The building was burnt down in 1270, repaired and expanded in 1278 . It was later repaired in the $14^{\text {th }}$ century.

The khan consists of a closed space and adjacent to the courtyard. There are two monumental portals in the building. One of them is the entry gate of the courtyard and the other is the entrance door of the closed space. The exterior of the building is made from the crown door that opens to the courtyard. There are a number octagonal section on the eastern front strut around every corner. ${ }^{45}$ The crown gates have reached the size of the day and are largely upright (see Figure $17)$.

44. Binan, 13. Yüzyıl Anadolu Kervansarayları Koruma Ölçütleri üzerine Bir Araştırma, 1990, 216.

45. Acun, Anadolu Selçuklu Kervansarayları, 2007, 142. 


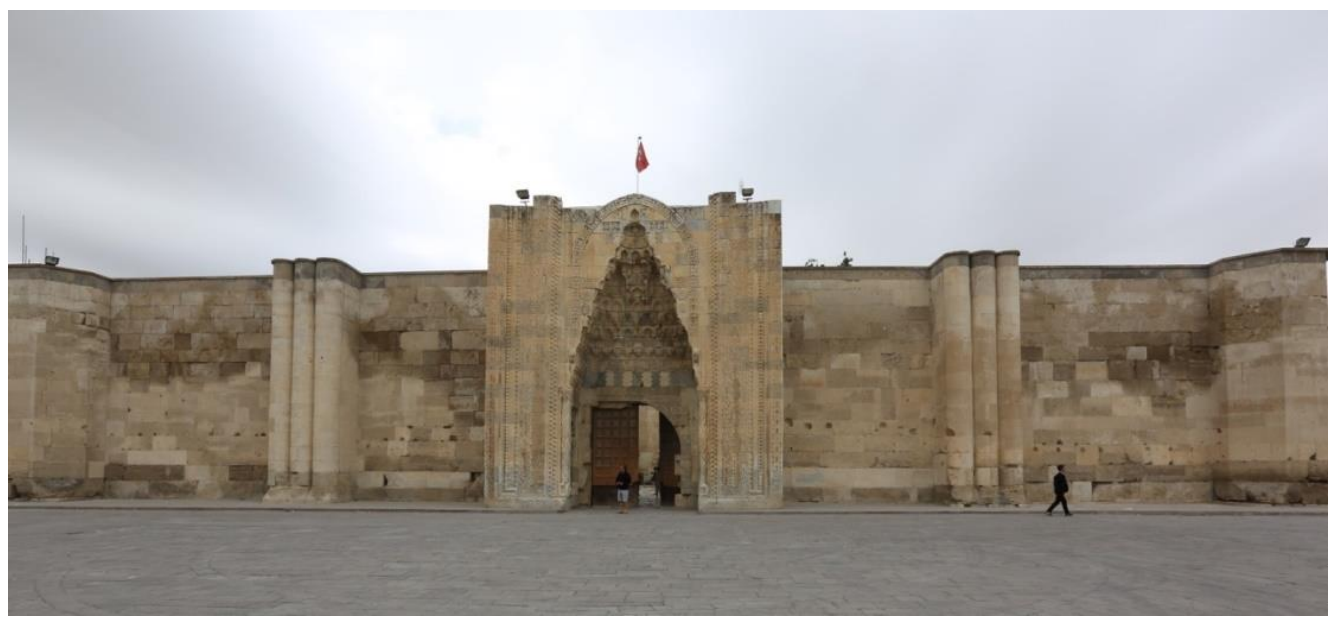

Figure 17. Aksaray Sultankhan East Section and Main Portal

Source: https://www.semerkanddanbosnaya.com/portfolio/sultanhani/.

On the east side, portal opens with a rectangular plan. There is a kiosk masjid in the center of the courtyard. ${ }^{46}$

The kiosk masjid with two-sided twin stepped stairs is square plan. The ruined mosque with its top cover was largely completed in its restoration work since it became ruined over time. ${ }^{47}$ (See Figure 17). It consists of portico spaces surrounding the courtyard. From courtyard passed to closed space. There is a portal that allows passage of the courtyard through the closed space.

There are three main aklands with a rectangular plan extending east-west. The ceiling height of the middle hall in the entrance axis is higher. There is a dome in the central symmetry center. The hall on both sides of the central hall is covered with pointed arches. It is arranged in four rows in the east-west direction and raised on four square piers joined by pointed arches. ${ }^{48}$

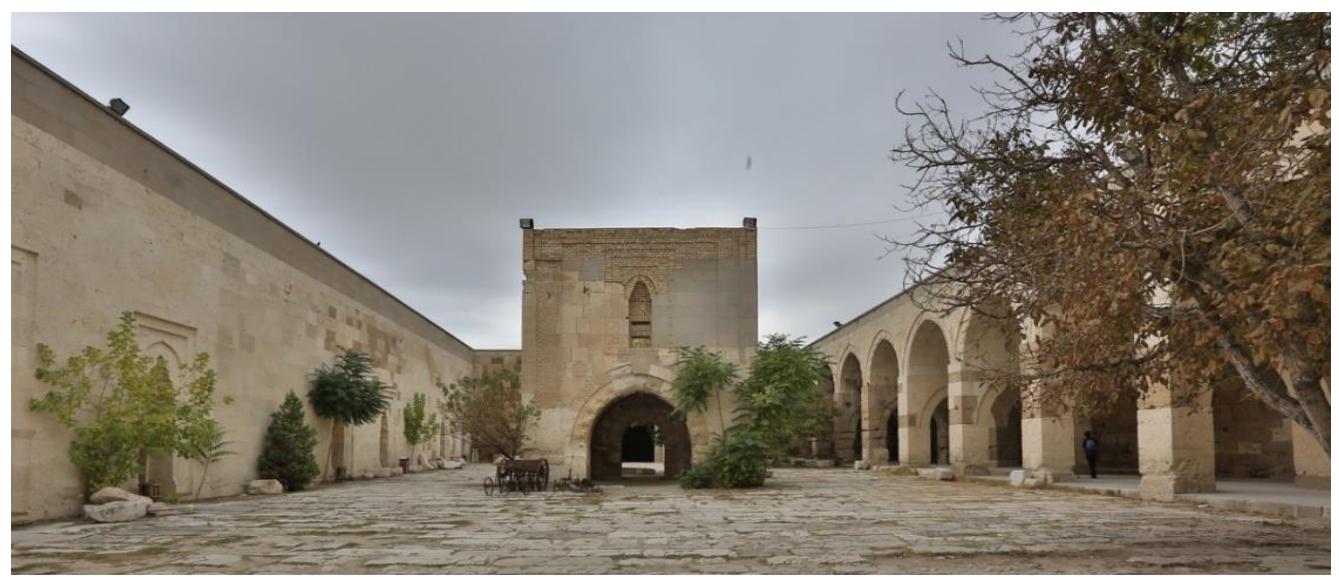

Figure 18. Aksaray Sultankhan Kiosk Masjid

Source: https://www.semerkanddanbosnaya.com/portfolio/sultanhani/.

46. Ibid, 143.

47. Binan, 13. Yüzyıl Anadolu Kervansarayları Koruma Ölçütleri üzerine Bir Araştırma, 1990, 191.

48. Acun, Anadolu Selçuklu Kervansarayları, 2007, 144. 


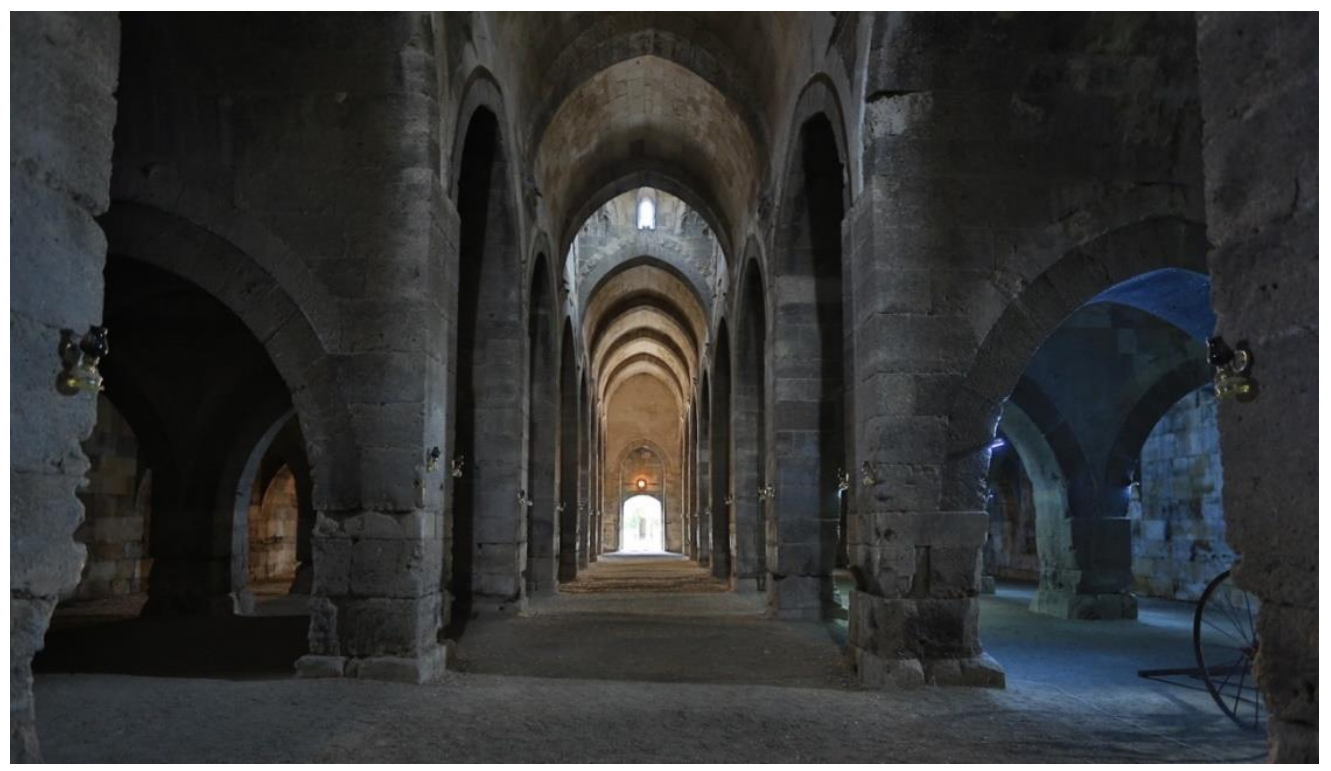

Figure 19. Aksaray Sultankhan Closed Space

Source: https://www.semerkanddanbosnaya.com/portfolio/sultanhani/.
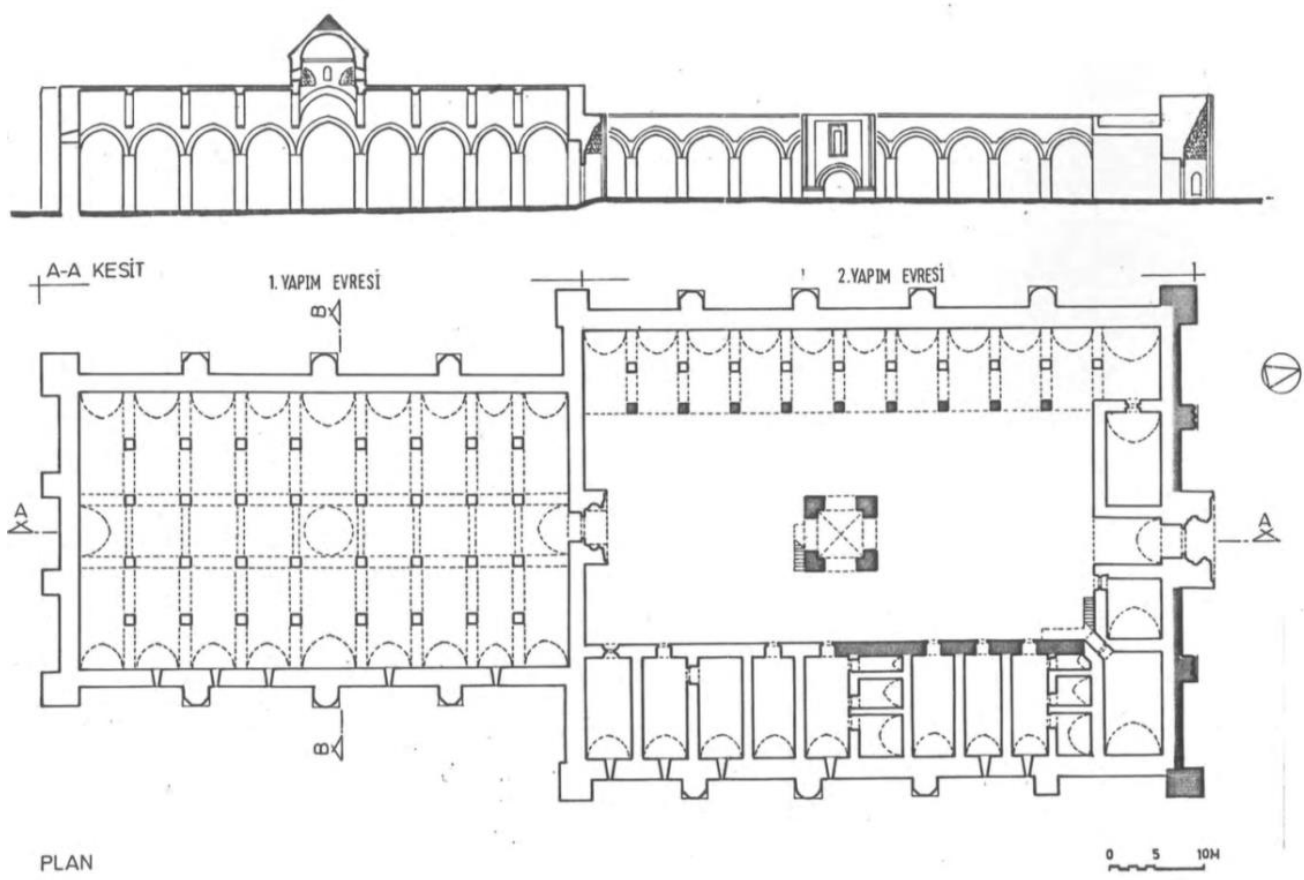

Figure 20. Aksaray Sultankhan Plan and Section

Source: Binan, C., (1990). 13. Yüzyıl Anadolu Kervansarayları Koruma Ölçütleri üzerine Bir Araştırma, Doktora Tezi, İTÜ Fen Bilimleri Enstitüsü, İstanbul, 203).

Courtyard planned caravanserais

This typology, which is generally seen in the Southeastern Anatolia Region, is similar to the plan of the caravanserais of the Arabian geography. The spaces around the courtyard form an axially symmetrical plan. The examples of this 
structure are more limited than the other caravanserais and khans in Anatolia. ${ }^{49}$ An example is Evdir Han, which has this typology reaching daily in Anatolia (see Figure 21).

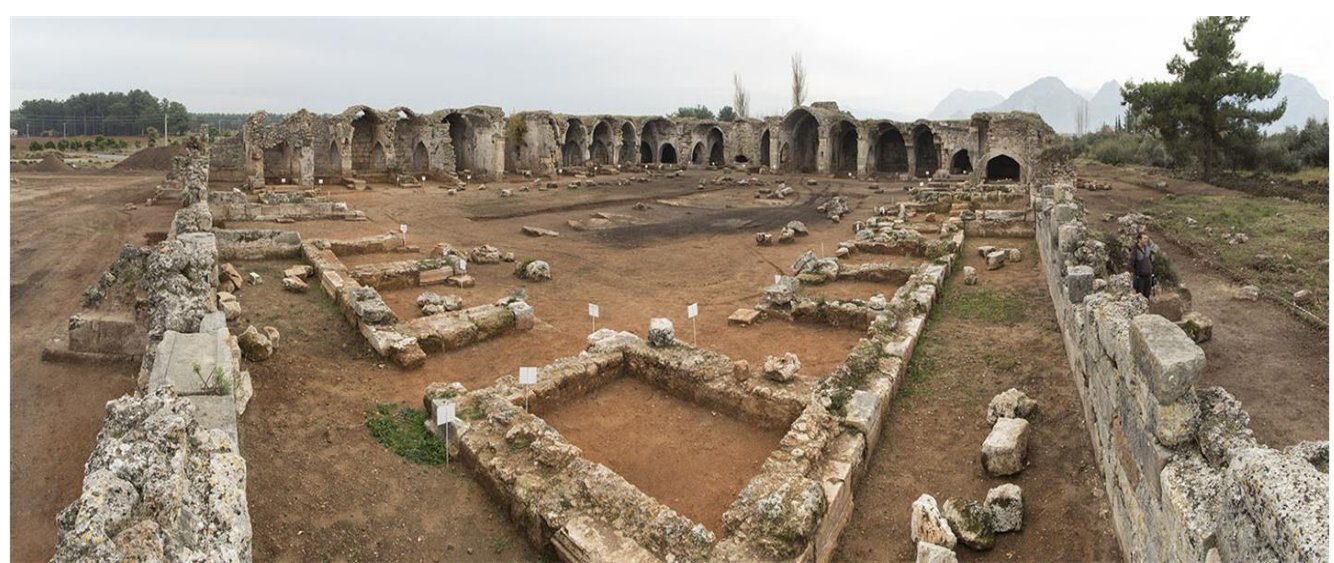

Figure 21. Evdir Khan(Antalya) Courtyard and Ruins

Source: http://www.dosemealti.bel.tr/tr/m/tarihi-yerler/evdir-han.html.

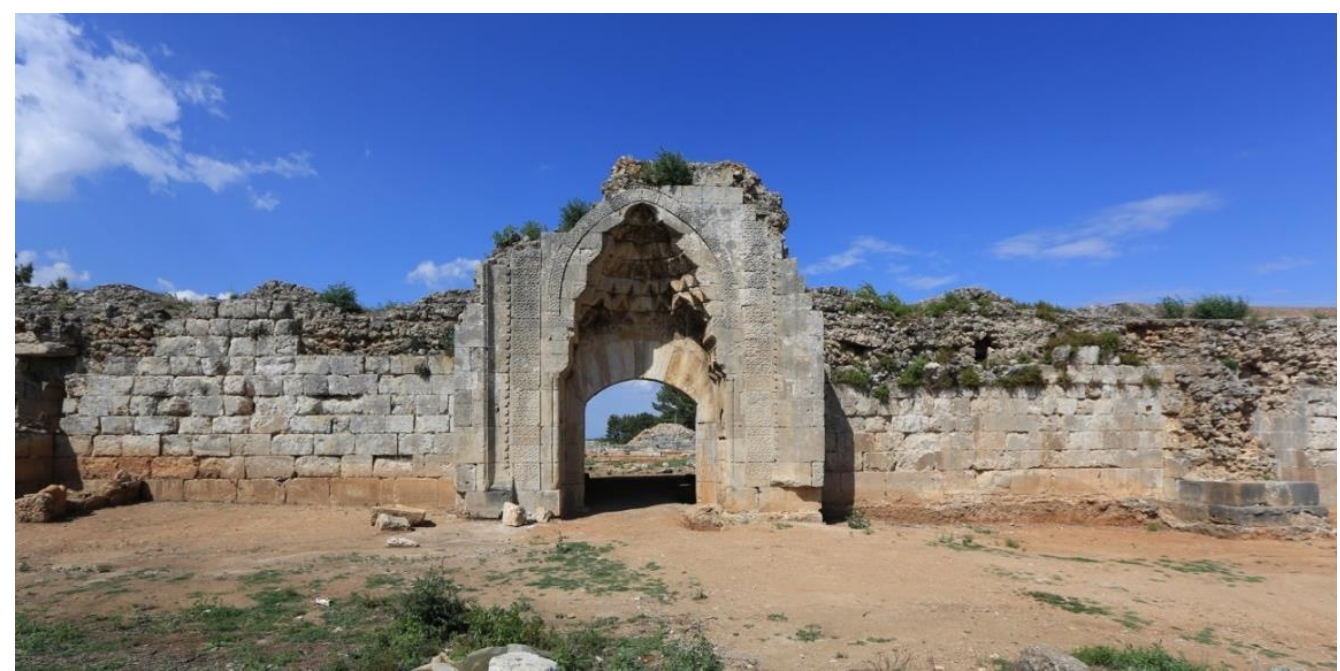

Figure 22. Evdir Khan Portal

Source: https://www.semerkanddanbosnaya.com/portfolio/evdir-han/.

It is the first stop of the caravans from Antalya on Burdur road in Antalya. The rectangle in the middle consists of spaces shaped around a large courtyard. There is an iwan (eyvan) at the midpoint of each edge. The portal on the south facade was opened.

The most monumental structural element of the building is the portal (see Figure 28). Although the portal is largely devastated, the stone dressing and muqarnases on it have been reached to date.

49. Binan, 13. Yüzyll Anadolu Kervansarayları Koruma Ölçütleri üzerine Bir Araştırma, 1990, 248. 


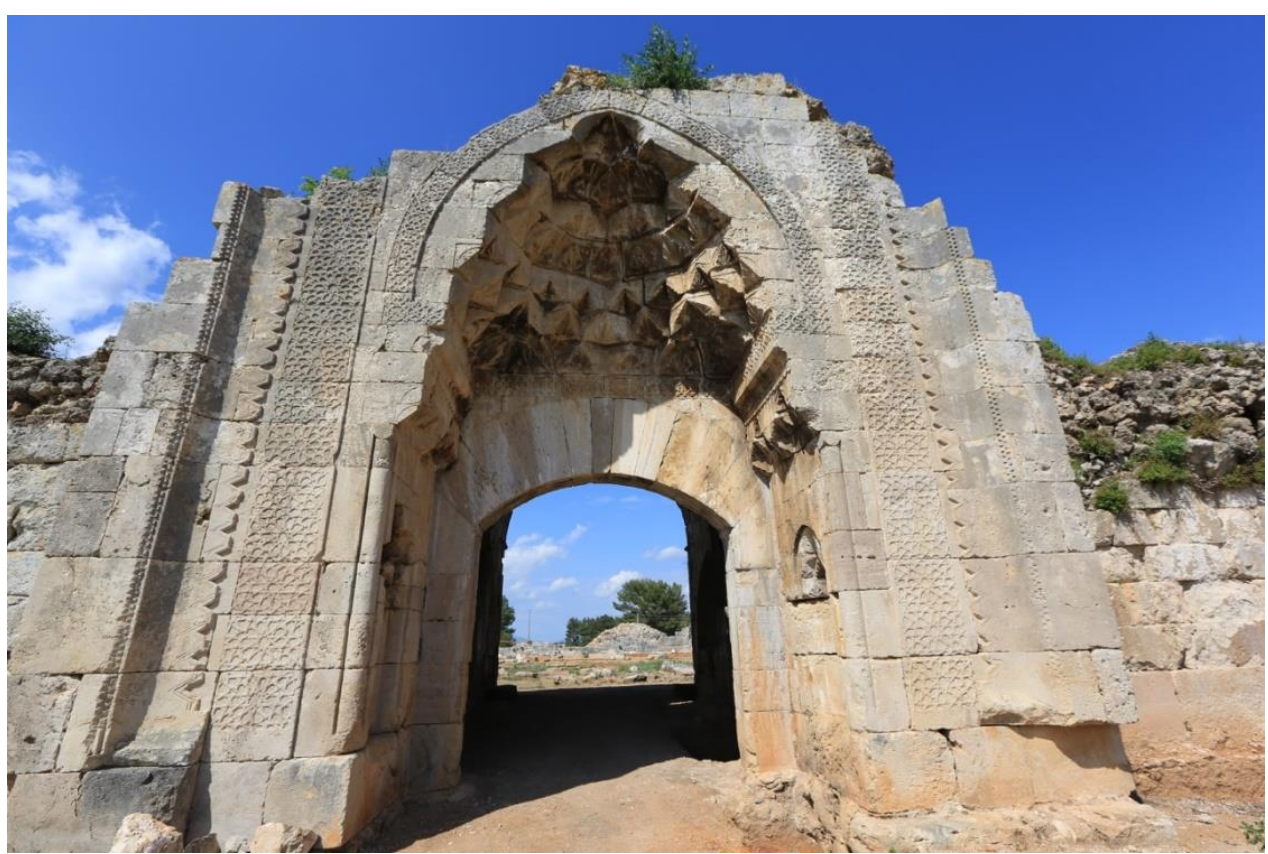

Figure 23. Evdir Khan Portal

Source: https://www.semerkanddanbosnaya.com/portfolio/evdir-han/.

A large part of the porticos that surround the courtyard from all four sides has been ruined. The roofs of the eastern and southern porticoes reached up to date. Only the body walls of the porticoes in the other parts remain. ${ }^{50}$ (See Figure 24).

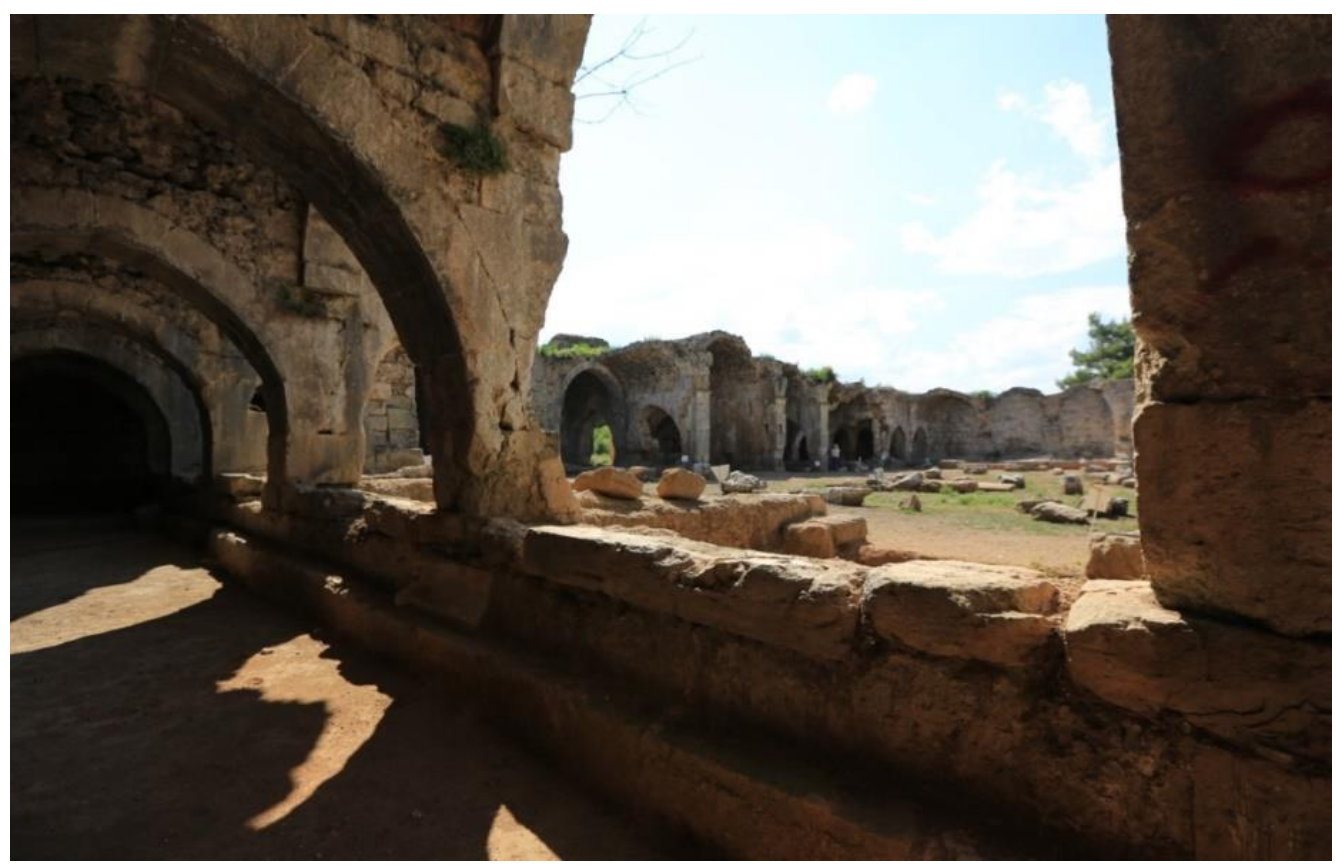

Figure 24. Evdir Khan Indoor

Source: https://www.semerkanddanbosnaya.com/portfolio/evdir-han/.

50. Acun, Anadolu Selçuklu Kervansarayları, 2007, 423. 


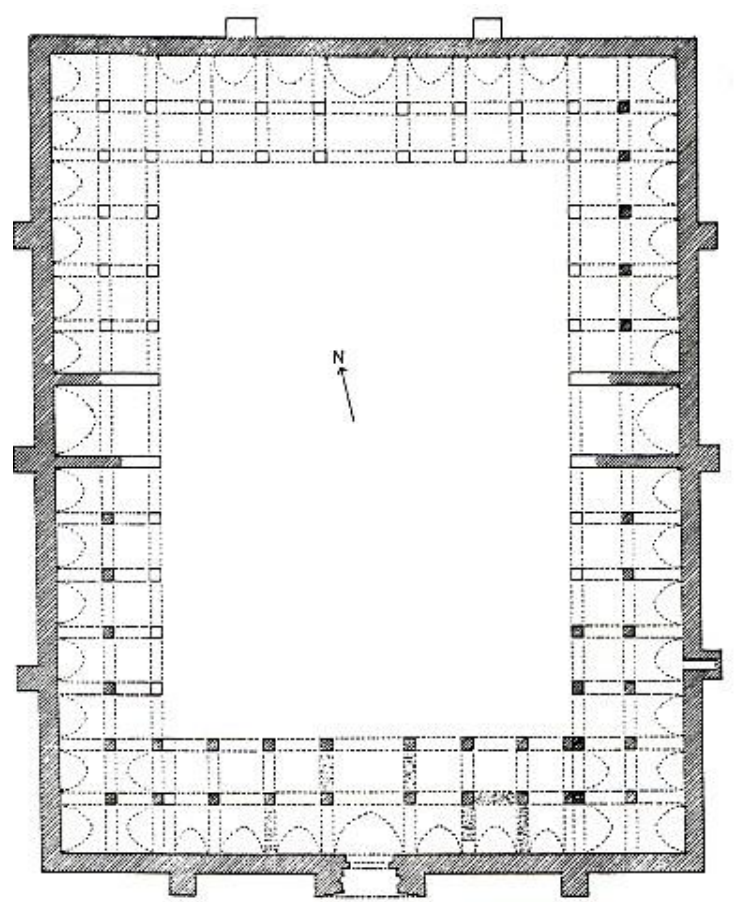

Figure 25. Evdir Khan Plan

Source: http://www.turkishhan.org/evdir.html.

Concentric planned caravanserais

These constructions, which are limited in Anatolia, are the most advanced type of caravanserai plan typology. The fact that it has been used in different geographies may be a sign that it is not affected by climatic differences. The places are different according to the functions. Most of the places are reserved for caravans. The room, the layout of the iwan, and the rooms are different day and night. There are barns on the outermost layer of the structure. ${ }^{51}$ Concentric planned caravanserais create an original typology with plan features and space constructions. $^{52}$

In Anatolia, for example, Alara Khan, Eshab-1 Kehf Khan and Mama Hatun Caravanserai can be given as examples of concentric planned khans and caravanserais. Erdmann in studies on these structures, drew attention to the similarities between the Alara Khan and Eshab1-1 Kehf Khan. Ünal also pointed out the similarities between Mama Hatun Caravanserai and Eshab-i Kehf Khan.

Alara Khan which is one of the caravanserai having concentric planned typology is in the north-south line of the Seljuks caravan roads. According to the stone tablet, the year of construction is 1231. It was built by Sultan Alaaddin Keykubat period.

51. Binan, 13. Yüzyıl Anadolu Kervansarayları Koruma Ölçütleri üzerine Bir Araştırma, 1990, 249.

52. A. Yavuz Tükel, “Anadolu'da Eşokdalı Selçuklu Hanları,” ODTÜ Mimarlık Dergisi II/2 (1976), 187. 
The portal is between the two struts on the north side. There is a stone tablet of two parts on the portal. ${ }^{53}$

In the planning scheme; it is understood that the central parts of the structure serve the travelers and caravans. In the same direction as the entrance gate of the khan, it is entered through a flat arched portal. In this section, the spaces are arranged around a central corridor. Places formed line in the form of an arm, an iwan. There are four rooms and three iwans on each side. It is understood from this plan scheme that spaces are reserved for day and night use. The rooms are used for iwans day to night. This reveals the unique side of the caravanserai. It was demolished in the middle of the hallway on the top cover. Other spaces are covered with a pointed vault. ${ }^{54}$ (See Figure 26).

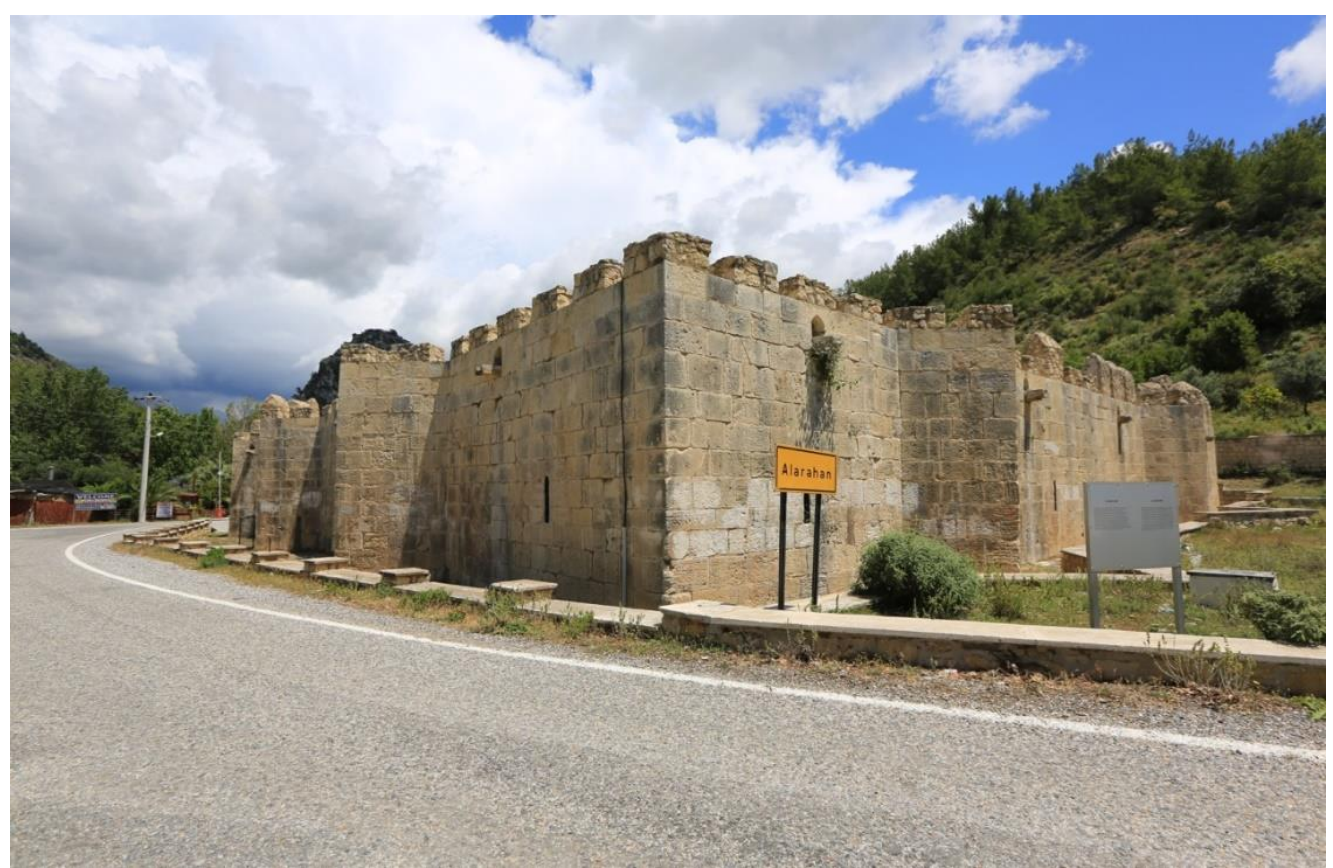

Figure 26. Alara Khan(Antalya) General View

Source: https://www.semerkanddanbosnaya.com/portfolio/alara-han/.

There are a number of service spaces on the outside of the khanplan in the north, in front of the central part and behind the outer wall in the north of the khan. The organization of these places is made open yard where the portal of the khann is opened. The entrance and exit gate of the khan, the middle section and the corridors opening in the service spaces open this courtyard (see Figure 26).

The long side of the northern corridor where the courtyard is opened is limited to the middle part (the part reserved for the accommodation of the passengers) in the south and the fountain, the iwan and the two rooms in the north. The two corridors are opened to the galleries. From there, service areas are provided. ${ }^{55}$

53. Binan, 13. Yüzyll Anadolu Kervansarayları Koruma Ölçütleri üzerine Bir Araştırma, 1990, 42.

54. Yavuz Tükel, “Anadolu’da Eşokdalı Selçuklu Hanları,” 1976, 189.

55. Ibid. 
Surrounding the central portion is located on the south, west and the east direction gallery. The outermost row of these galleries forming two rows in the interior forms the barns. In the barns the animals are connected and fed. The interior galleries have created spaces for the khan staff and the residents. In addition to this, the caravan's cargoes are stored in the galleries inside (see Figures 27-28).

In order to separate the inner gallery space from the barn, 'seki' was created. Interior gallery spaces are about 70-80 cm higher than stables. It can be said that the residents observe their belongings and their animals in the spaces opened to the galleries from the places in the middle part. The building receives light from the narrow, long tilted windows that open out on the outer walls and from spaces in vaults. Candils on the consoles in arches are provided with the lighting at the night. $^{56}$

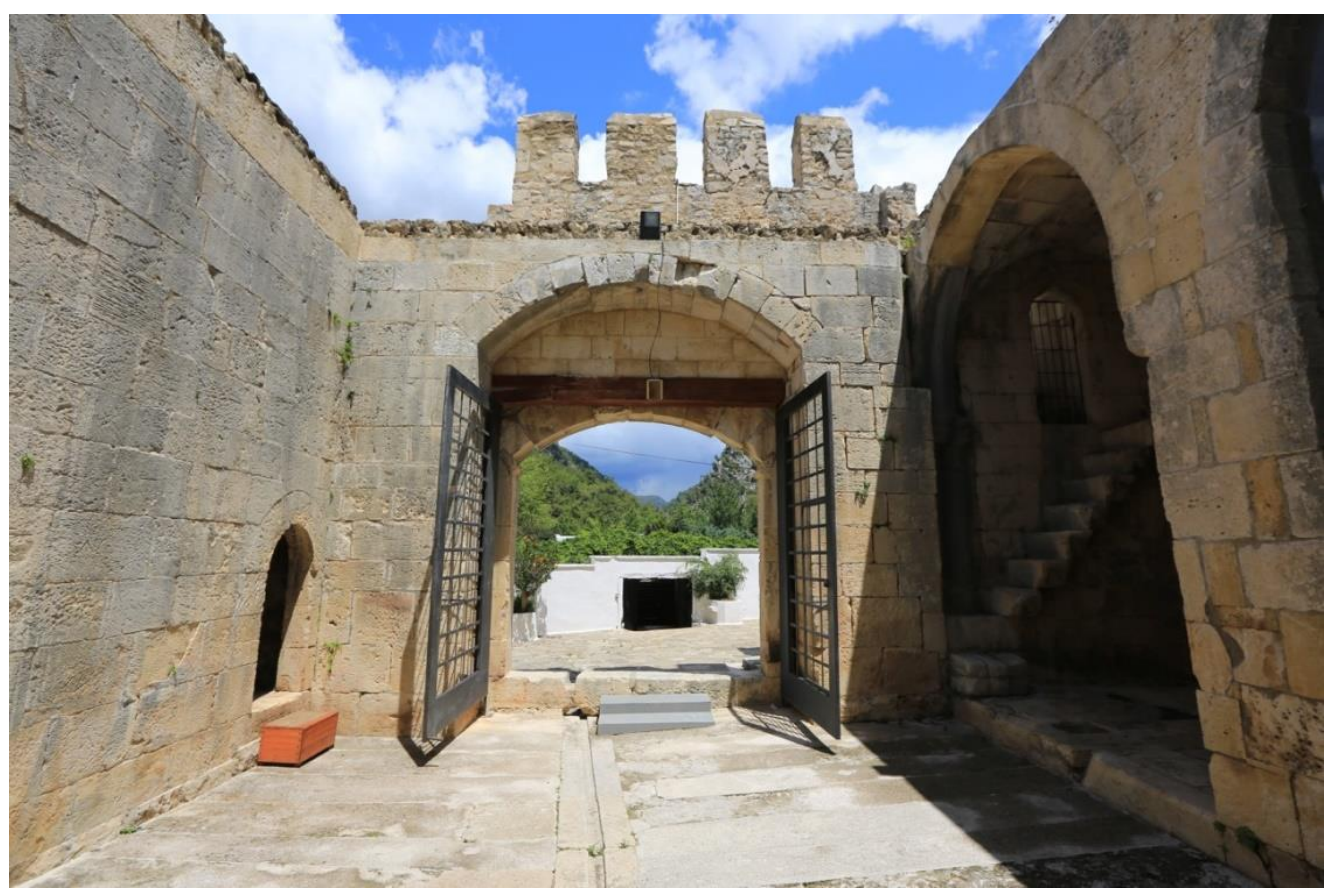

Figure 27. Alara Khan Indoor and Portal

Source: https-//www.semerkanddanbosnaya.com/portfolio/alara-han/3.jpg.

The top cover of the bark is the soil roof. The roof of the upper cover did not prevent water from getting in the roof. So, melted the porous limestone used on the walls of structure. . $^{2}$

56. Ibid.

57. Binan, 13. Yüzyıl Anadolu Kervansarayları Koruma Ölçütleri üzerine Bir Araştırma, 1990, 43. 


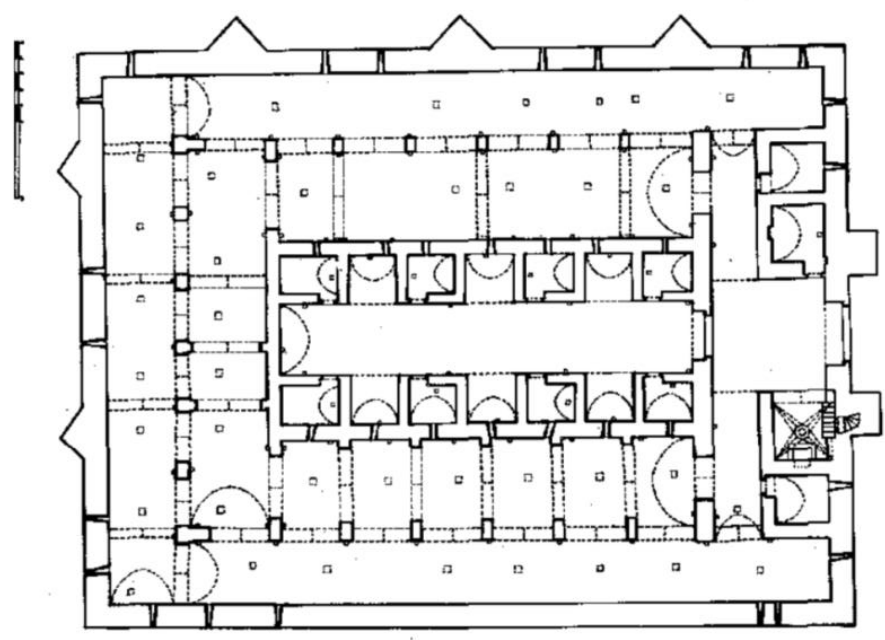

$\triangleright$

Figure 28. Alara Khan Plan

Source: Binan, C., (1990). 13. Yüzyıl Anadolu Kervansarayları Koruma Ölçütleri üzerine Bir Araştırma, Doktora Tezi, İTÜ Fen Bilimleri Enstitüsü, İstanbul, 203).

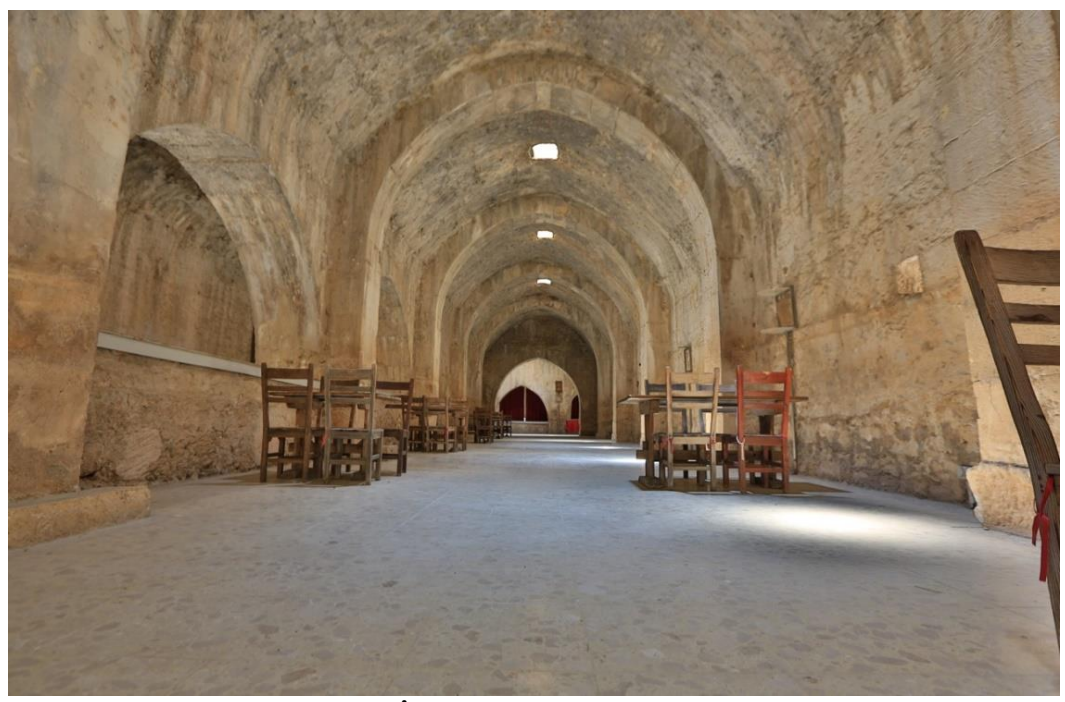

Figure 29. Alara Khan Indoor

Source: https://www.semerkanddanbosnaya.com/portfolio/alara-han/.

We can say that, compared to other types of caravanserai typology, the concentric planned caravanserai which has not much samples outside of Anatolia has a more advanced plan design. These caravanserais, which are among the most important examples of Anatolian Seljuk architecture, vary in size depending on their location and user. ${ }^{58}$

58. Yavuz Tükel, “Anadolu'da Eşokdalı Selçuklu Hanları,” 1976, 199. 
In addition to the foundation caravanserais in Anatolia, there are also smallscale caravanserais built by people to meet needs for caravans. Located on Kayseri-Aksaray road, Sarı Khan can be an example of this construction.

There are two portals with a rectangular planned courtyard and a closed structure. The courtyard was added later as seen in the other examples. The exterior walls of the building have undergone major repairs and completion since they have been damaged to a great extent (Figures 30-32).

To the north of the portal, on the eastern of the courtyard, there is a hanging stone stairs, rising by separating into two opposite arms. The stairway leading to the north leads to the roof of the khan, the other to the entrance to the masjid.

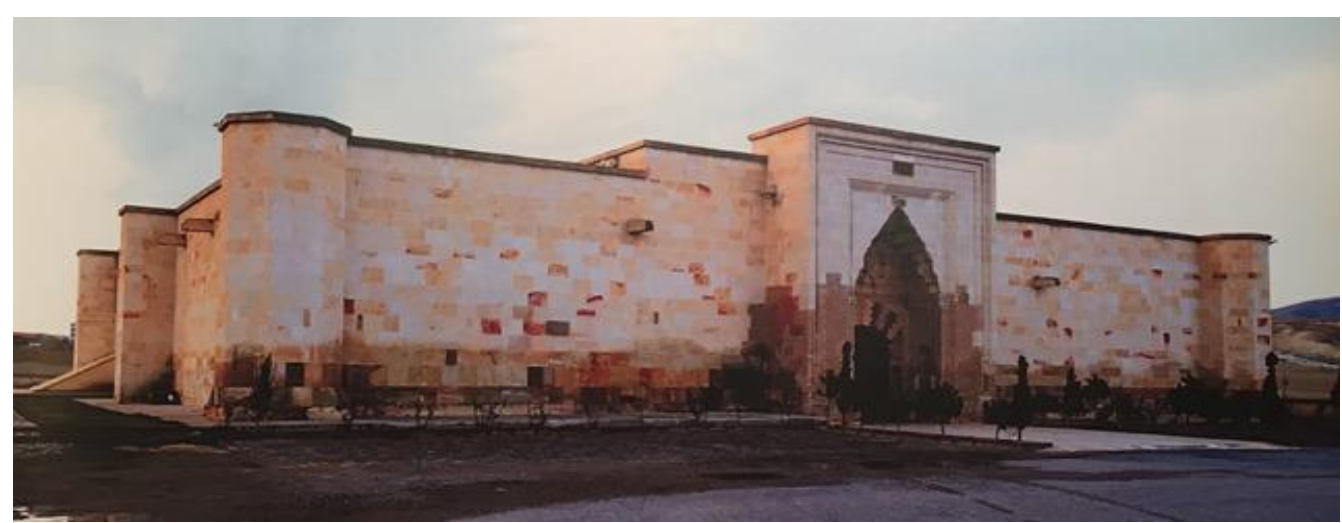

Figure 30. Sarı Khan (Nevşehir) General View

Source: http://www.turkishhan.org/sari.htm.

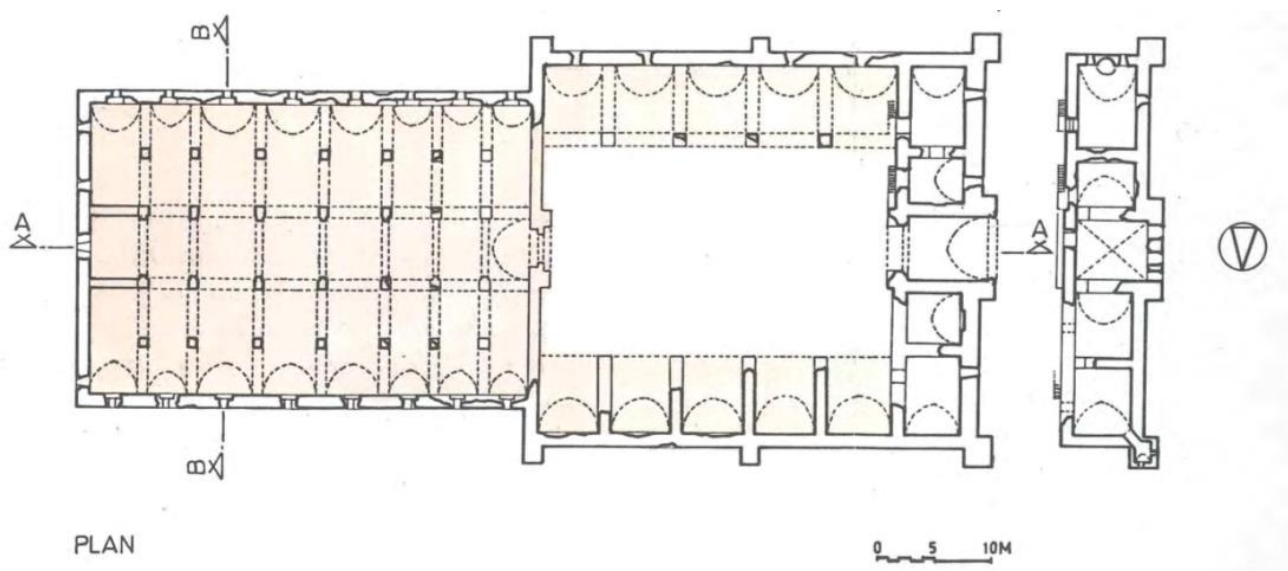

Figure 31. Sarl Khan Plan

Source: Binan, C., (1990). 13. Yüzyıl Anadolu Kervansarayları Koruma Ölçütleri üzerine Bir Araştırma, Doktora Tezi, İTÜ Fen Bilimleri Enstitüsü, İstanbul, 189. 


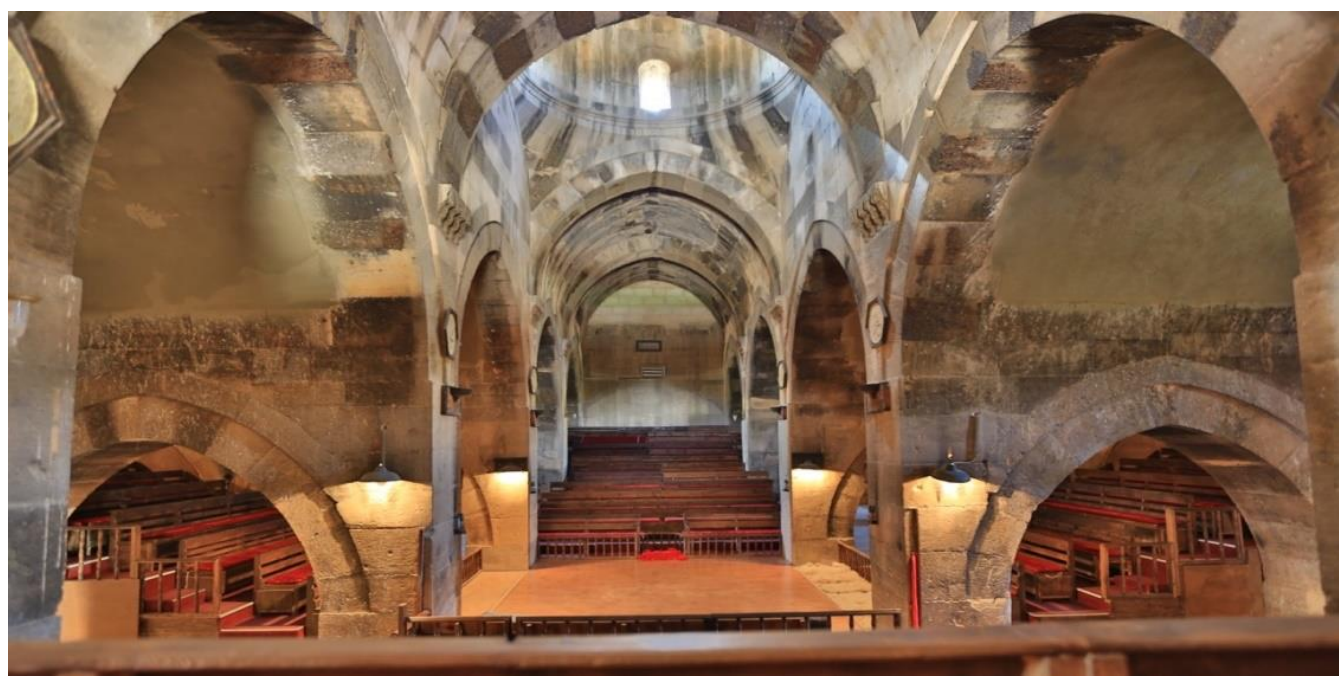

Figure 32. Sarl Khan Closed Space

Source: https://www.semerkanddanbosnaya.com/portfolio/sarihan/.

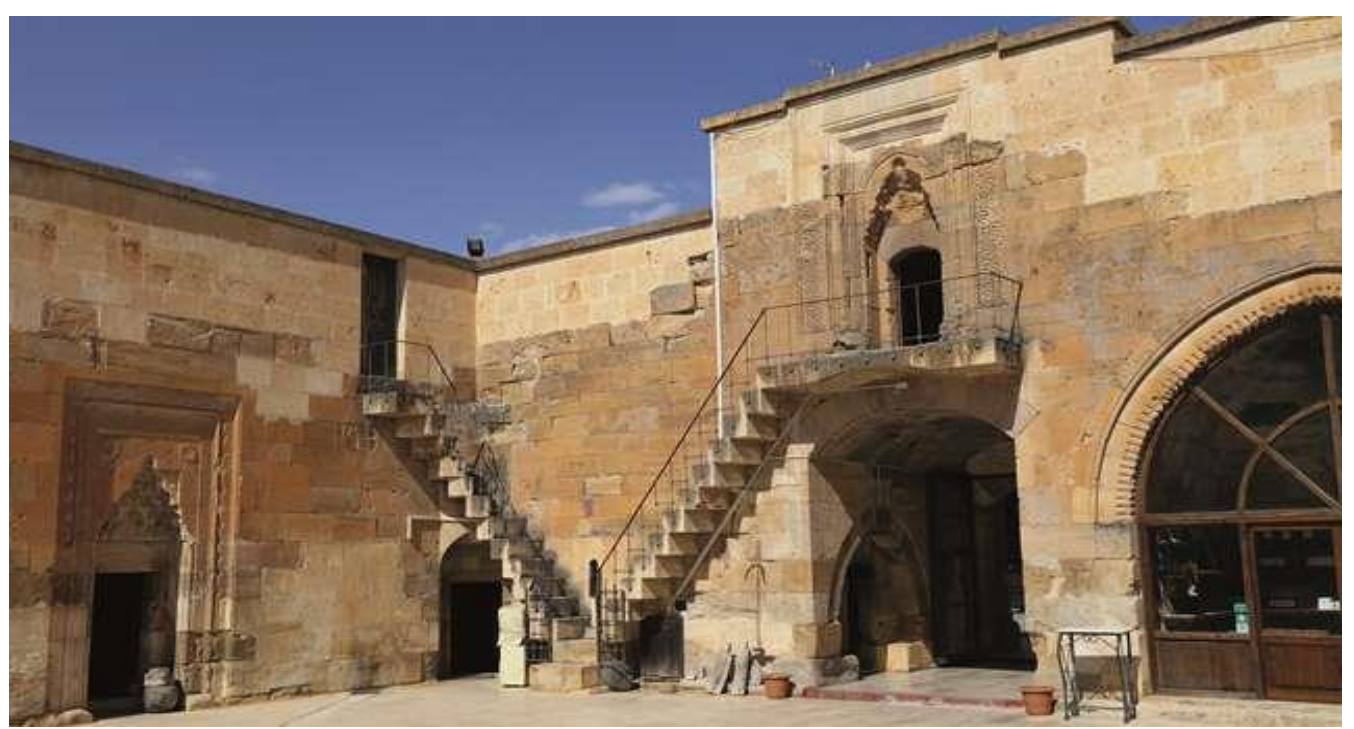

Figure 33. Sarl Khan Masjit

Source: https://www.semerkanddanbosnaya.com/portfolio/sarihan/.

Portals

The facades of the caravanserais are quite simple. Facades given a castle view are mostly built with cut stone or rubble stone. The most glamorous elements of the constructions are the 'portals' which are the only connection point outside. The portals give a dynamic appearance to the saphenous lining. It has supported the monumental appearance of the building. It is usually exceed the height of the props for building and construction in the middle. It protrudes over the facade surface. As a result, the depth of the niche opened on the facade has increased. This created a more unobtrusive image. The vegetation and geometric designs of 
the Seljuk stone artwork are carved into the stones with great skill. ${ }^{59}$ (See Figures 34-36).

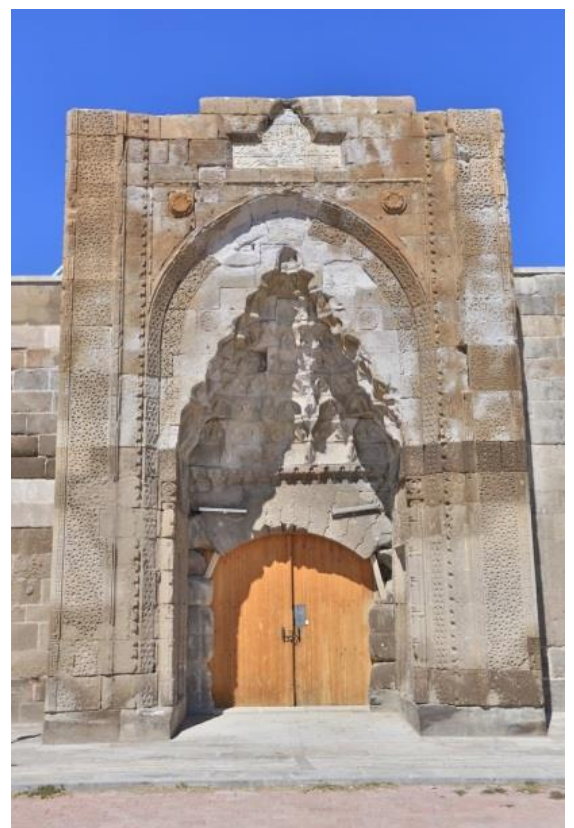

Figure 34. Karatay Khan (Kayseri) Facade and Portal

Source: https://www.semerkanddanbosnaya.com/portfolio/karatay-han/.

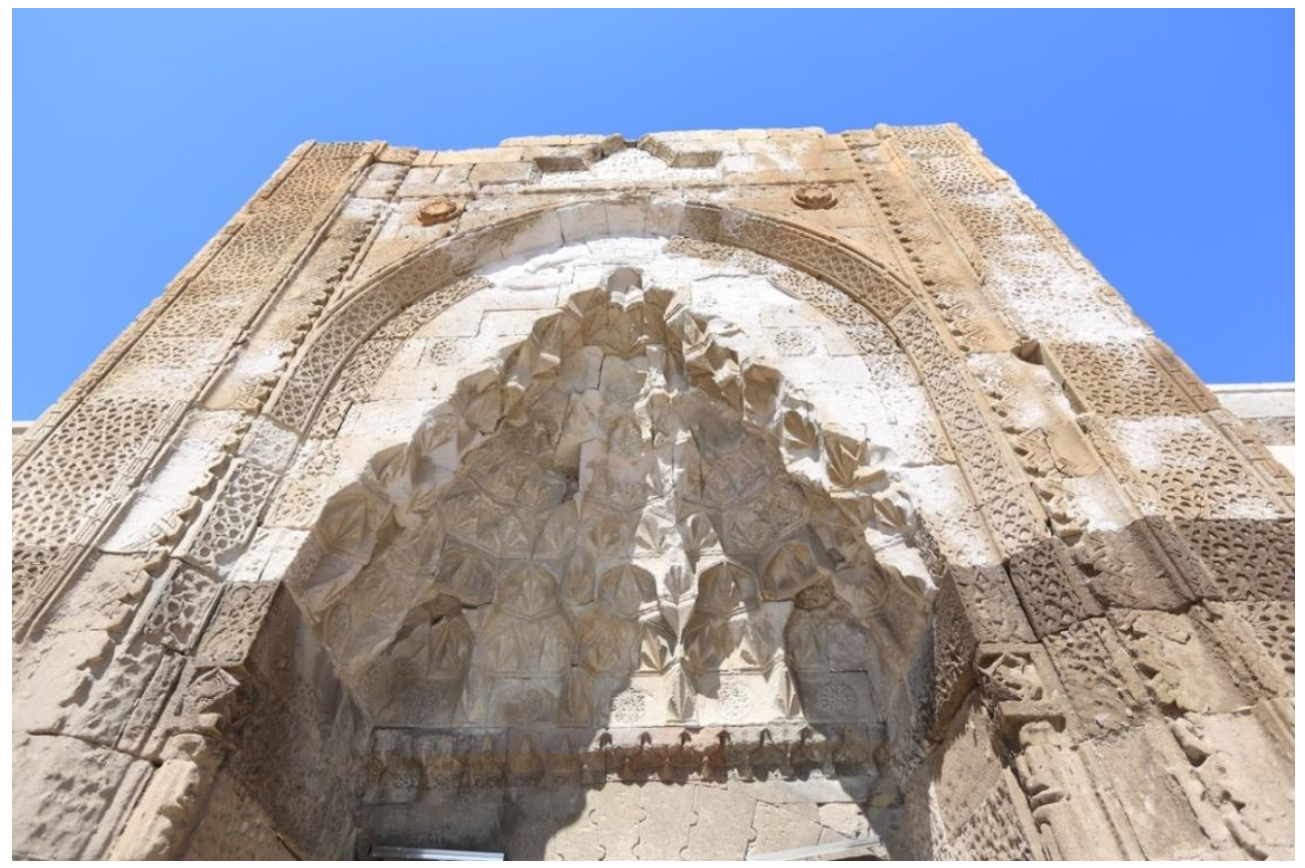

Figure 35. Karatay Khan Portal Muqarnas Detail and Ornamentation Source: https://www.semerkanddanbosnaya.com/portfolio/karatay-han/.

59. Ç. Erberk, "Anadolu Selçuklu Dönemi Taçkapıları Süsleme Şeritlerinde Tenziyat," Pamukkale Üniversitesi Illahiyat Fakültesi Dergisi, Denizli 3, no. 5 (2016): 115. 


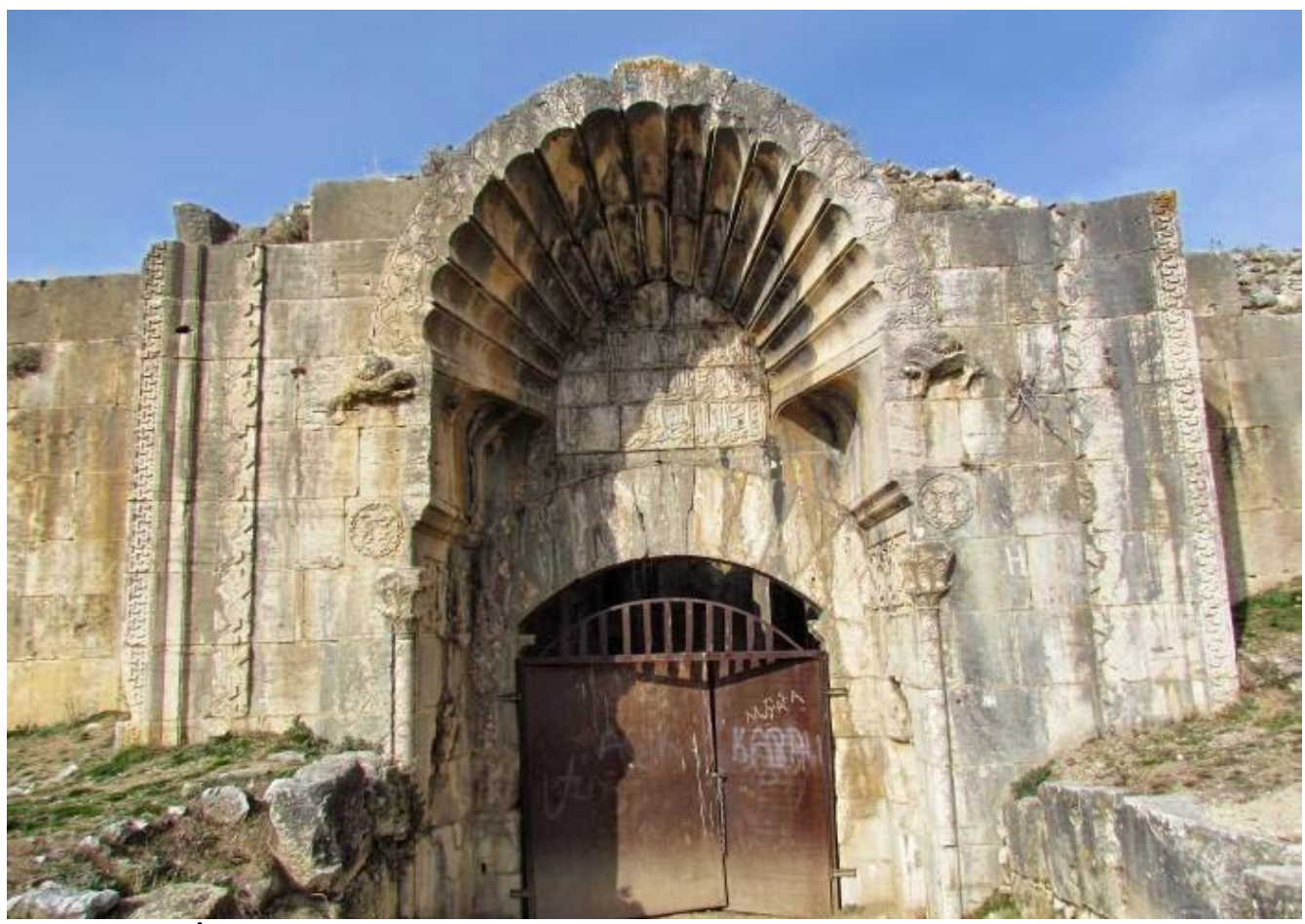

Figure 36. Incir Khan (Burdur) Portal

Source: https://www.toroslardayasam.com/2014/10/incir-han-burdur-ilibucak-ilcesi-snrlar.html.

Apart from the portals, other architectural elements attracting attention on the facades of the caravanserai have also become struts. They are not as magnificent and embroidered as portals. It is mostly used to strengthen facades and walls from a static point of view. In addition to the strengthening function, it gave a stable, strong expression to the structure in simple and geometric form. ${ }^{60}$

The struts are usually placed symmetrically on the facades. In some large caravanserais and sultankhans, the struts were placed in the facades. In the facades, generally triangular, rectangular, half octagonal, star and sliced geometric shapes are used (see Figures 37-38). These geometric shapes were used in $3 / 4$ of the cupboards at the corners. ${ }^{61}$

60. D. Kuban, Selçuklu Çă̆ında Anadolu Sanatı (İstanbul: Yapı Kredi Yayınları, 2002), 249.

61. Tükel Yavuz, Anadolu Selçuklu Kervansaraylarında Mekân-İşlev İlişkisi Iç̧inde Savunma ve Barınma. IX. (Ankara: Vakıf Haftası Kitabı, 1992), 255. 


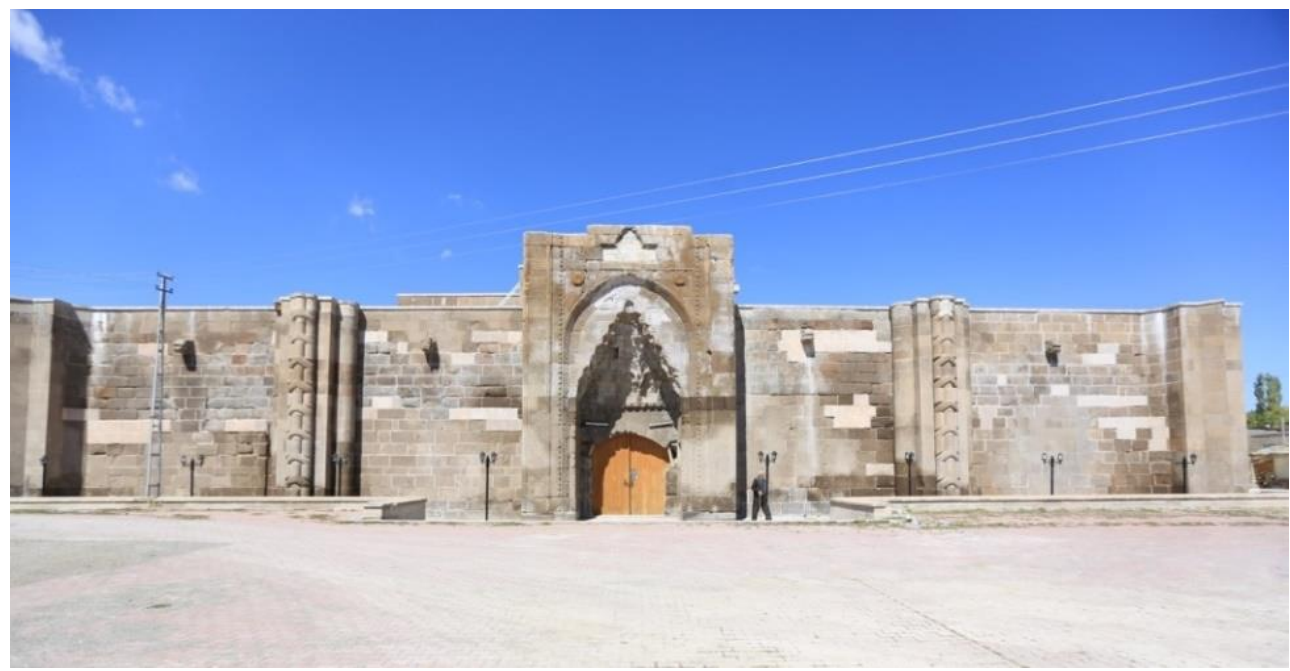

Figure 37. Karatay Khan (Kayseri) Facade and Portal, Struts

Source: https://www.semerkanddanbosnaya.com/portfolio/karatay-han/.

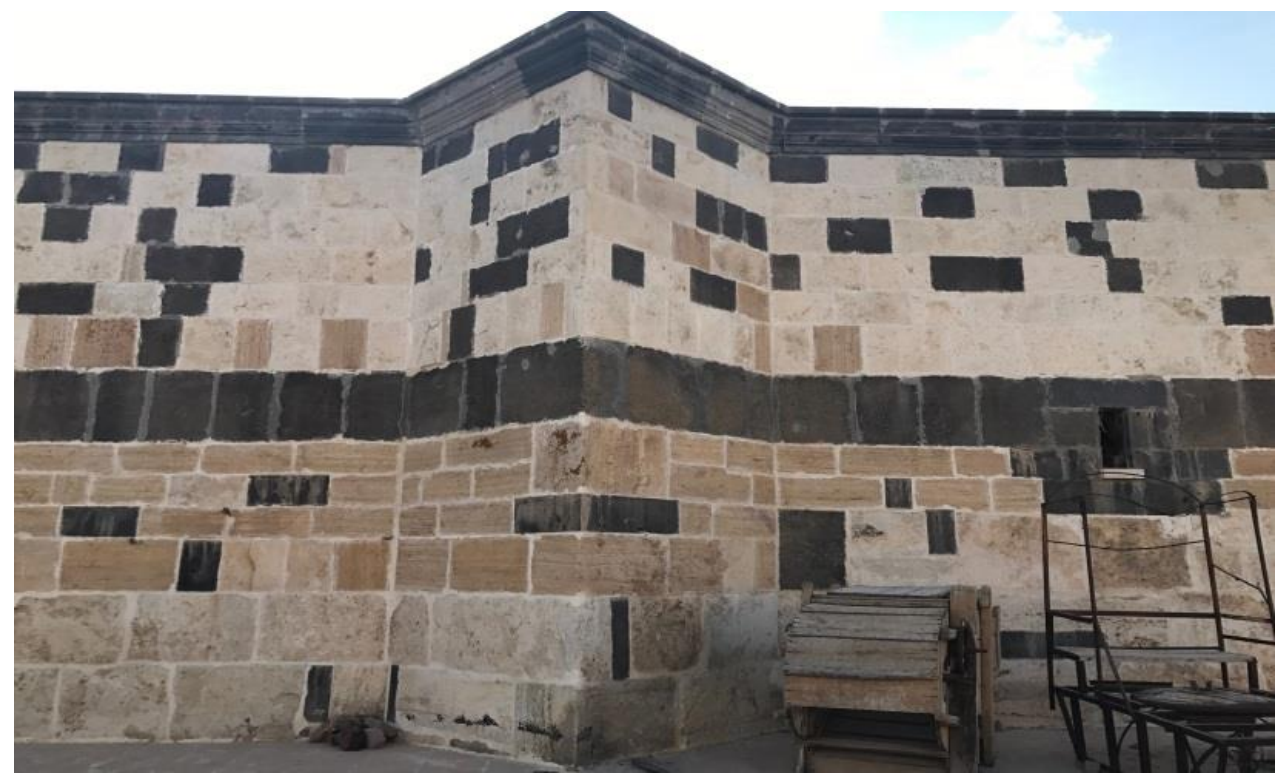

Figure 38. Alacahan(Sivas) Facade ve Triangular Strut

Source: Eylül, 2018.

\section{Kiosk Masjids}

There are storeage, warehouses, baths, mosques, etc. in the caravanserais. Masjids in the caravanserais of Anatolian Seljuks became one of the most important places. In the first Turkish states and ribats, there are masjids along with service spaces. For masjids there is no specific place in the planning of the plan. It is usually positioned in the direction of the entrance gate. Some examples include masjids located on the second floor. In this construction, Sousse Ribat, Tunisia can be an example.

There are various plan typologies in Anatolian Seljuk caravanserais. For this reason, no specific place for masjids has been shown. As in the first Turkish states, 
there are examples of entrance. In some cases, mosques are found adjacent to closed spaces. An example of this is Şarapsa Khan. ${ }^{62}$

Apart from these examples, there are examples of the masjids located in the middle of the courtyard. These masjids which are unique to Anatolian Seljuk caravanserai are called 'kiosk masjid'. Generally, stands in the middle of the courtyard, raised on four square piers joined by pointed arches (see Figures 39-40). There are also polygonal examples of these mosques in the Ottoman Empire which are also found in city khans.

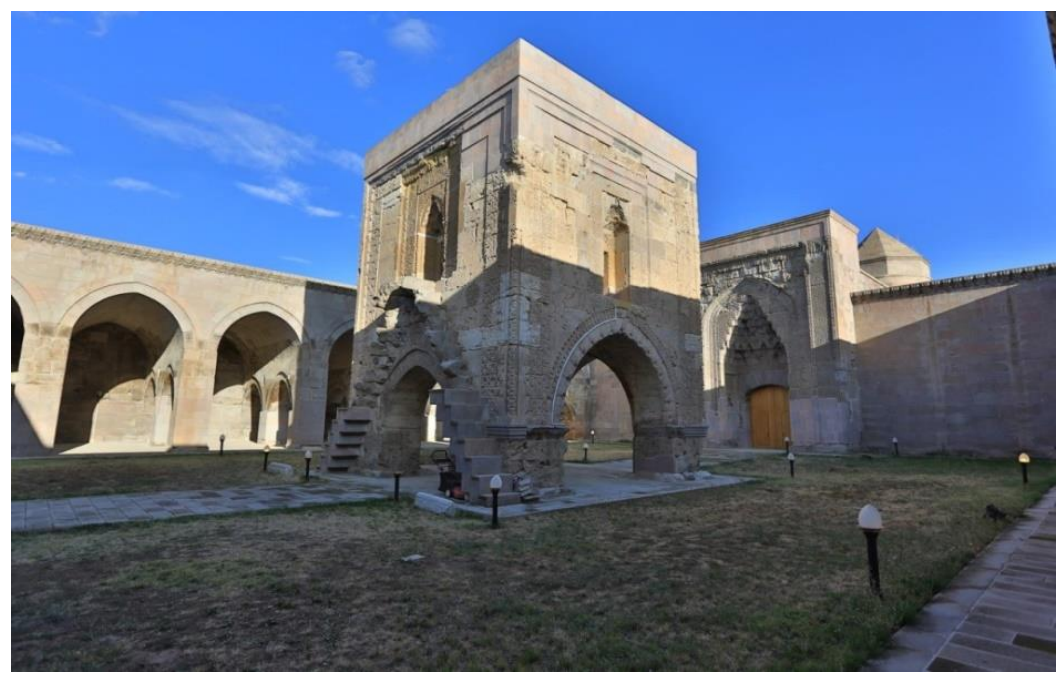

Figure 39. Ăgzlkarahan(Aksaray) Kiosk Masjid

Source: https://iyikivariz.com/2018/04/17/kapadokya-gezilecek-yerler/kapadokya-gezilecek-yerlerag\%CC\%86zikarahan/.

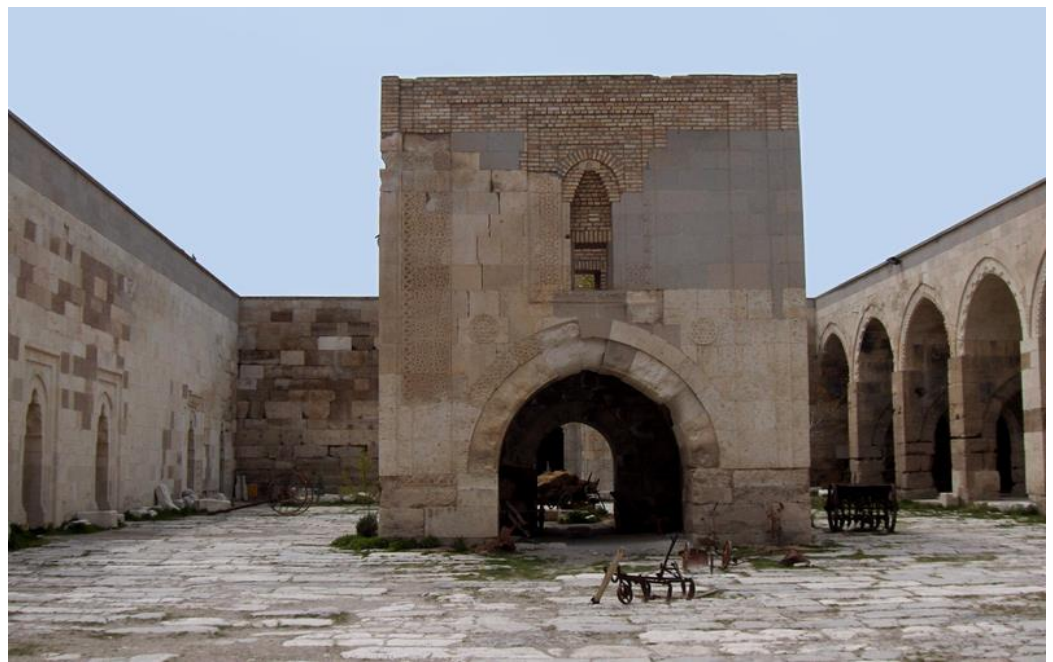

Figure 40. Sultankhan (Aksaray) Kiosk Masjid

Source: https://commons.wikimedia.org/wiki/File:Turkey.Aksaray004.png.

62. A. Denknalbant, Anadolu Selçuklu Kervansaray Mescitleri. Yüksek Lisans Tezi. (İstanbul: Sosyal Bilimler Enstitüsü, İstanbul Teknik Üniversitesi, 2004), 23. 


\section{Conclusions}

The ongoing trade concept with the existence of mankind has always been an economic and administrative power for the states. In history, great civilizations, states used trade to build political authority and strengthen economies. They needed a transportation system to make trade more efficient and to go to more regions. For this reason, great civilizations gave great importance to the construction and preservation of roads. Cultural exchanges have been made besides commercial shopping thanks to the links between countries and civilizations.

With the development of trade, goods and services have crossed the borders of the states. Long journeys have been made. On these journeys for months, accommodation and accommodation for travelers and caravans were needed.

When we look at the chronologically accommodation, we can say that it has a history that dates back to the before Christ. From the Assyrians, who have strong trade ties, the concept of trade has developed as much as every day. However, in order to meet the needs of passengers it was built on the road. During the Roman, Byzantine eras, constructions were built with a purpose of accommodation within a short distance on the roads in Anatolia and other geographical areas. The ribats that saw the first examples of Islam in the emerging geographical areas are buildings made with defense purposes. They have stayed in the country with the development of the borders and have provided accommodation services. These constructions which are quite simple are shaped according to their climate characteristics. Because the air temperature is generally high, it is composed of a large courtyard and portico units that revolve around it. In the Seljuks, who had seized trade in Anatolia since the $11^{\text {th }}$ century, the Ribat left their place in caravanserais.

The Seljuks extended their territory in the $10^{\text {th }}$ and $11^{\text {th }}$ centuries and gradually took control of Anatolia. The Seljuks gave importance to the commercial. Many caravanserais were constructed on the Anatolian roads, especially on the roads connecting important cities such as Konya, Sivas, Kayseri and Malatya.

We can say that Anatolian Seljuk caravanserais, which developed over time, is an original architectural style. Unlike the ribats, the plan of the caravanserais which consist of closed spaces and courtyard has developed according to economic conditions. Considering the cold winter months in Anatolia, the closed section was first built to meet the caravan's security and security needs. Then the courts were added with the improvement of the conditions, the increase of the economic level and the expansion of the requirement list. This typology comes across Anatolia, especially in the construction of Seljuk caravanserais (see Figure 41). 


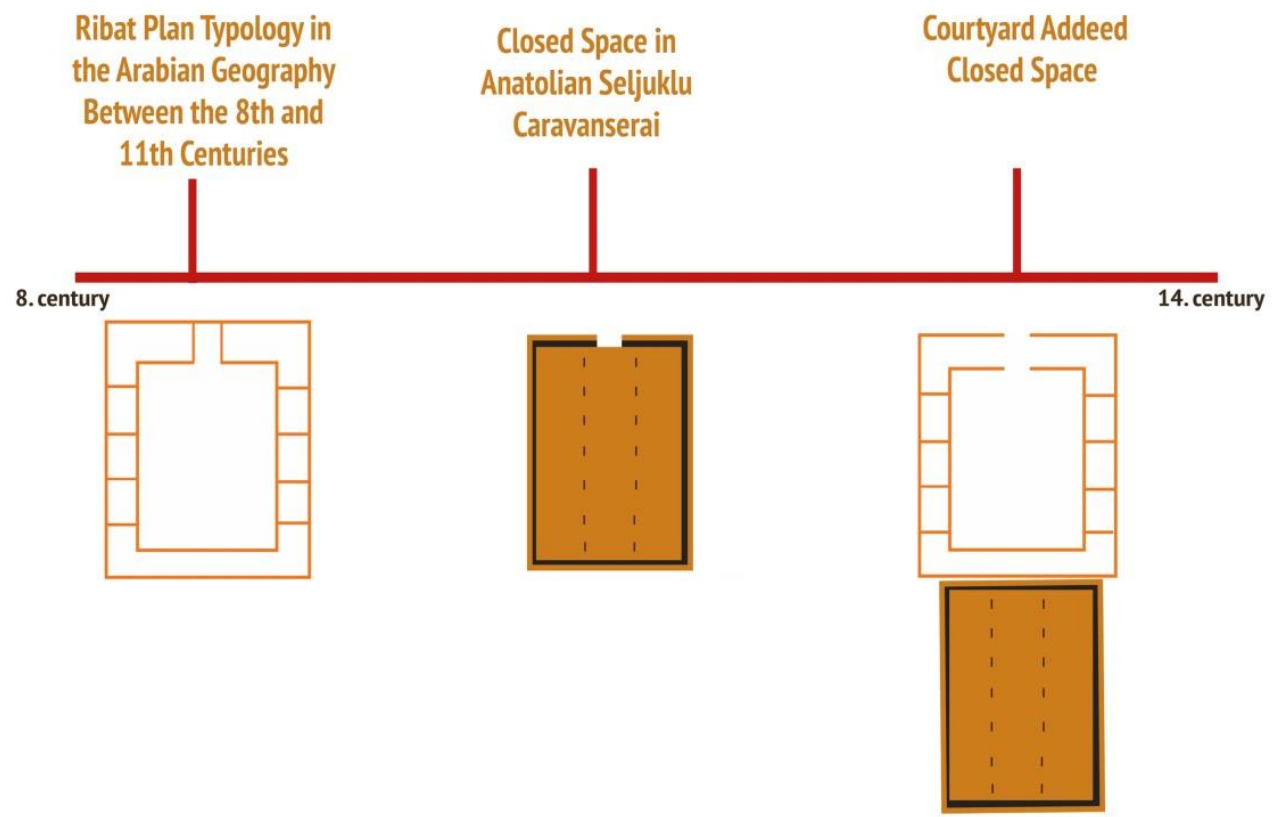

Figure 41. Schematic Diagram of Open and Closed Use in Ribat and Anatolian Seljuk Caravanserais

Source: Darendeli, 2018.

Another plan typology seen in the Anatolian Seljuks is the 'concentric planned khans'; it is the most developed caravanserai species. Other civilizations in BC, accommodation structures with various typologies in Roman, Byzantine and Arabian geography; in Anatolia, the needs have changed considerably over time.

The caravanserais, which were used effectively during the Seljuk period, later lost their importance to the caravan roads and left their place in the inner city khans. Today, with the change of roads, it has been difficult to function in the caravanserais in the countryside. Today, khans in the city are given accommodation and commercial functions.

\section{Bibliography}

Acun H. Anadolu Selçuklu Kervansarayları. [Anatolian Seljuk Caravanserais.] Ankara: T.C. Kültür Bakanlığı Yayınları, 2007.

Atasoy, F. Yükselen İpekyolu 3. [Volume 3 of the Rising Silk Road'Cilt.] Ankara: Türk Yurdu Yayınları, 2016.

Baş, A. Beylikler Dönemi Hanları. [Khans of the Principalities Period.] SÜ, SBE, 1989.

Binan, C. 13. Yüzyll Anadolu Kervansarayları Koruma Ölçütleri üzerine Bir Araştırma.

[A Research on the Criteria of Conservation of Anatolian Caravanserai in the $13^{\text {th }}$ Century.] Doktora Tezi. İstanbul: İTÜ Fen Bilimleri Enstitüsü, 1990.

Çetin, E. "Franz Taeschner'in Muhtelif Devirlerde Anadolu'nun Yolları Ve Cihan Münakalatına Nazaran Vaziyeti İSsimli Eseri ÜzeriNe Notlar." [Notes on Franz Taeschner's book titled The Paths of Anatolia in Various Periods and their Controversy.] Tarih Okulu Dergisi 17 (2014).

Denknalbant, A. Anadolu Selçuklu Kervansaray Mescitleri. [Anatolian Seljuk Caravanserai Masjids.] Yüksek Lisans Tezi. İstanbul: Sosyal Bilimler Enstitüsü, İstanbul Teknik Üniversitesi, 2004. 
Erberk, Ç. "Anadolu Selçuklu Dönemi Taçkapıları Süsleme Şeritlerinde Tenziyat." [Decoration in Ornamental Ribbons of the Anatolian Seljuk Period Crown Gates.] Pamukkale Üniversitesi İlahiyat Fakültesi Dergisi, Denizli 3, no. 5 (2016).

Eskikurt, A. "Ortaçağ Anadolu Ticaret Yolları." [Medieval Anatolian Trade Roads.] Sosyal Bilimler Enstitüsü Dergisi, Muğla (2014).

Karacan, S., E. Karacan and Y. Güngör. "Osmanlı'da Konaklama Hizmeti Veren Yapılardan Gebze Çoban Mustafa Paşa Kervansarayı.” [Gebze Çoban Mustafa Pasha Caravanserai, One of the Structures that Provide Accommodation in the Ottoman Empire.] III.Disiplinlerarast Turizm Araştırmaları Kongresi Bildiri Kitabl, III.Disiplinlerarası Turizm Araştırmaları Kongresi, 2014.

Karacan, E., S. Karacan and Y. Güngör. "Tarihsel Süreç İçinde Konaklama Merkezleri Han ve Kervansarayların Günümüzde İpek Yolu Projesine Dönüşümü.” [Transformation of Accommodation Centers, Inns and Caravansaries to the Silk Road Project in the Historical Process.] 5.Doğu Akdeniz Turizm Sempozyumu ve I. Uluslararası Doğu Akdeniz Turizm Sempozyumu, Nisan, Doğu Akdeniz Üniversitesi Turizm Fakültesi, KKTC, 2016.

Kuban, D. Selçuklu Çağında Anadolu Sanatı. [Anadolu Anatolian Art in the Seljuk Period.] İstanbul: Yapı Kredi Yayınları, 2002.

Osman T. "Selçuklu Kervansarayları.” [Seljuk Caravanserais.] TTK Belleten X/39 (1946): 471-496.

Sönmez, S. "Ortaçağ Türk ve İslam Dünyasında Kervansaraylar (Hanlar - Ribatlar.)" [Caravanserais in the Medieval Turkish and Islamic Worlds (Khans - Ribats.)] Kâzım Karabekir Eğitim Fakültesi Dergisi, Erzurum (2007).

Turan, O. "Selçuk Kervansarayları." [Caravanserais of Seljuks.] T.T.K. Belleten X/39 (1946).

Ünal, H. R. "Antalya-Korkuteli Kervan Yolu Üzerinde Bilinmeyen Üç Han.” [Three Unknown Inns on the Antalya-Korkuteli Caravan Road.] Sanat Tarihi Dergisi XIX/1 (2010).

Yavuz Tükel, A. "Anadolu'da Eşokdalı Selçuklu Hanları." [Concentric Planned Khans of Seljuks.] ODTÜ Mimarlık Dergisi II/2 (1976). . Anadolu Selçuklu Kervansaraylarında Mekân-İşlev İlişkisi İçinde Savunma ve Bartnma. [Defense and Housing in the Relation of Space-Function in the Anatolian Seljuk Caravanserais.] IX. Ankara: Vakıf Haftası Kitabı, 1992. 
